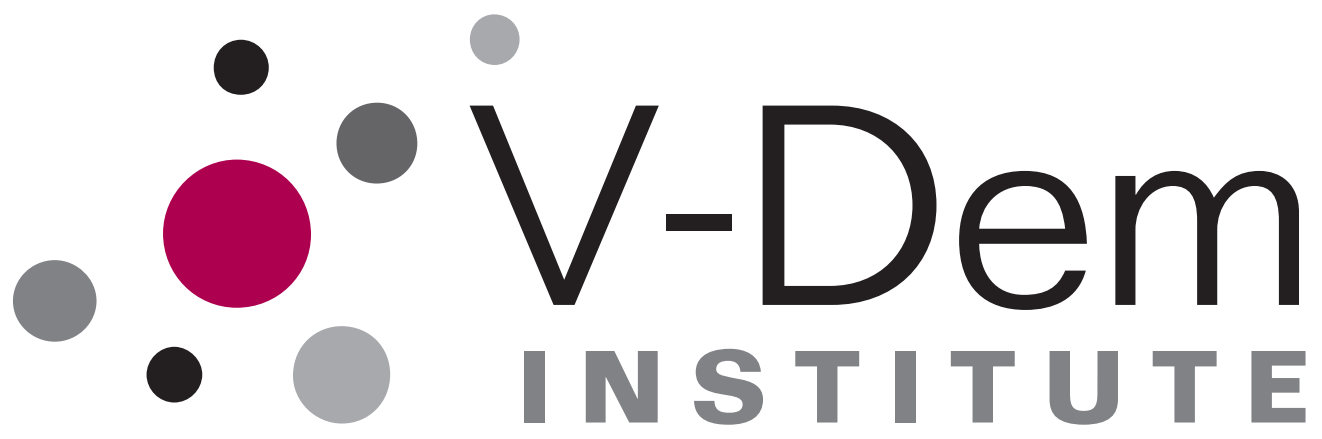

00000000000000000000

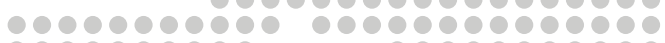
0

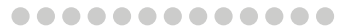
100000000900000

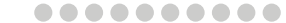

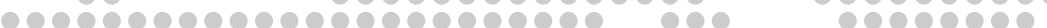

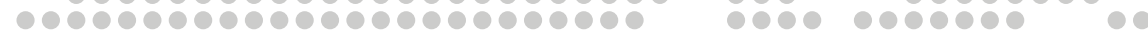

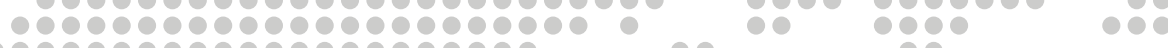

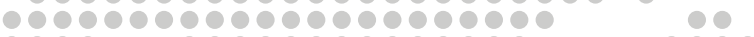
0000 ○.

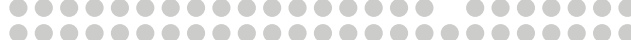

9090

100 10

10000

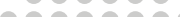

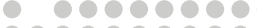

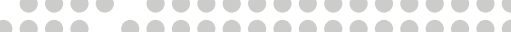

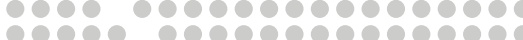
00000000000000000000

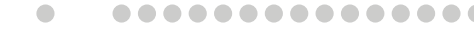
00000000000000000 ro מصو

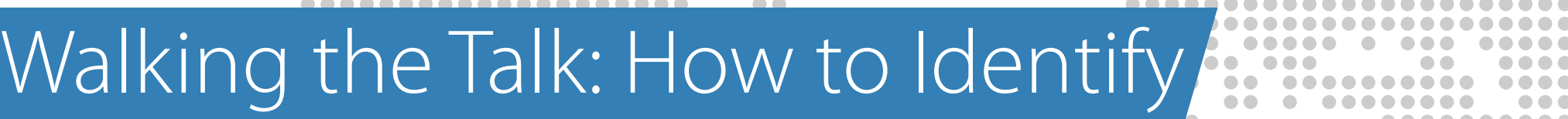

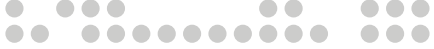

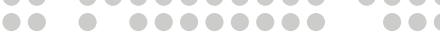

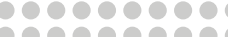
Anti-Pluralist Parties

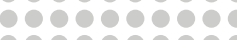

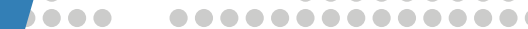


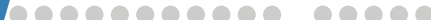

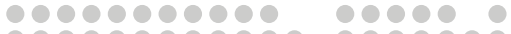

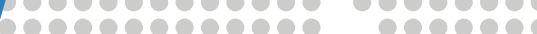

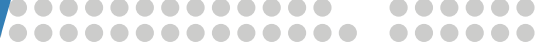

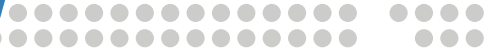

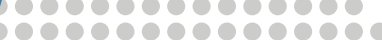

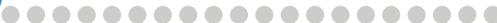

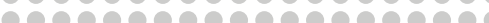

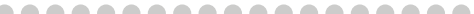

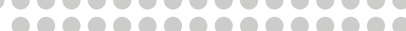

90000000000000

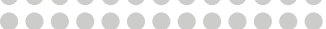

10000000000

0000000000

000000000

ö000000000

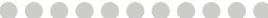

00000000000

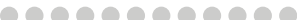
00000000 5090000

0000000 1000000 100000

000000

00000000

1000000

000000

1000

00

100000

10000

000

100

10

10

80

(1)

March 2021

Working Paper

SERIES 2021:116

THE VARIETIES OF DEMOCRACY INSTITUTE
UNIVERSITY OF GOTHENBURG

DEPT OF POLITICAL SCIENCE 
Varieties of Democracy (V-Dem) is a new approach to conceptualization and measurement of democracy. The headquarters - the V-Dem Institute - is based at the University of Gothenburg with 23 staff. The project includes a worldwide team with 5 Principal Investigators, 19 Project Managers, 33 Regional Managers, 134 Country Coordinators, Research Assistants, and 3,500 Country Experts. The V-Dem project is one of the largest ever social science research-oriented data collection programs.

Please address comments and/or queries for information to:

\author{
V-Dem Institute \\ Department of Political Science \\ University of Gothenburg \\ Sprängkullsgatan 19, Box 711 \\ 40530 Gothenburg \\ Sweden \\ E-mail: contact@,v-dem.net
}

V-Dem Working Papers are available in electronic format at www.v-dem.net.

Copyright (C2021 by authors. All rights reserved. 


\title{
Walking the Talk: How to Identify Anti-Pluralist Parties*
}

\author{
Anna Lührmann, Juraj Medzihorsky, and Staffan I.Lindberg \\ V-Dem Institute \\ Department of Political Science \\ University of Gothenburg
}

\footnotetext{
${ }^{*}$ We are grateful to Kyle Marquard and participants of the HSE Faculty of the Social Sciences Seminar Series (12/2020), the University of Hamburg (12/2020) and Gothenburg (1/2021) for helpful feedback and comments. This research was supported by Vetenskapsrådet [grant number 2018-016114], PI: Anna Lührmann, Knut and Alice Wallenberg Foundation to Wallenberg Academy Fellow Staffan I. Lindberg, Grant 2018.0144, and European Research Council, Grant 724191, PI: Staffan I. Lindberg, as well as by internal grants from the Vice-Chancellor's office, the Dean of the College of Social Sciences, and the Department of Political Science at University of Gothenburg. We thank Ana Laura Ferrari, Ana Good God, Palina Kolvani, and Sandra Grahn for skillful research assistance. This paper partially builds on Lührmann et al. (2020).
} 


\begin{abstract}
The recent increase of democratic declines around the world - "the third wave of autocratization" - has sparked a new generation of studies on the topic. Scholars agree that these days the main threat to democracy arises from democratically elected rulers, who gradually erode democratic norms once in power. Is it possible to identify future autocratizers before they win power in elections? Linz (1978) and Levitsky and Ziblatt (2018) argue that a lacking commitment to democratic norms reveals would-be autocrats before they reach office. Such anti-pluralist traits include demonizing rhetoric, the encouragement of political violence, disrespect for minority rights, and lacking commitment to the democratic process. Comparative political science researchers have not systematically collected and tested these potential early-warning indicators. This paper makes use of a new expert-coded data set on virtually all relevant political parties worldwide from 1970 to 2019 (V-Party) to provide the first systematic empirical test of this argument.
\end{abstract}




\section{Introduction}

The vanguard of democracy's contemporary enemies are paradoxically elected leaders and parties that once in power, erode democratic rights and institutions (Bermeo, 2016; Boese et al., 2020; Lührmann and Lindberg, 2019; Svolik, 2015). Once autocratization gets underway, democracies stand only about a $20 \%$ chance to avoid breakdown and democracy has broken down in 36 countries since the 1990s (Boese et al., 2020), mostly at the hands of parties and leaders once professing to be democrats. The key to democratic resilience that now preoccupies academic and policy communities is how to prevent autocratization to begin with. A first step is to answer the question: Can we identify the traits of political parties that erode democracy once in power?

Using a unique dataset on 1,943 political parties across 1,759 elections in 169 countries from 1970 to 2019 (Lührmann, Düpont, et al., 2020), this paper shows that we can identify such parties with surprisingly high precision. The traits that signify would-be autocratizers are the four characteristics suggested in Linz' canonical contribution from 1978: A rhetoric that is only "semiloyal" to democratic norms, values, and institutions (Linz, 1978). ${ }^{1}$ We provide a conceptualization of those traits as anti-pluralist, that signals of future authoritarianism. We show how this differs from other suggestions such as populism (Mudde and Kaltwasser, 2013; Müller, 2017; Norris and Inglehart, 2019) and ideology, and demonstrate with the first ever systematic test of how well the traits of these three partially competing ideas identify seemingly democratic but will-be-autocratic parties before they come into power.

This approach in this paper follows a long tradition in comparative politics emphasizing that political elite actors rather than structural conditions decide the fate of democracy. The work of Linz (1978) is canonical. Similarly, Bermeo (2003) argues cogently that elite action-not mass attitudes and behavior - were the final bow to every major case of democratic collapse in the $20^{\text {th }}$ century. More recently, Mainwaring and Pérez-Liñán (2013) also stress that elite actors are key to explaining the ups and downs of democracy in Latin America in the post-Second World War era.

The approach in this paper follows a long tradition in comparative politics emphasizing that political elite actors rather than structural conditions decide the fate of democracy (e.g. Bermeo, 2003; Linz, 1978; Mainwaring and Pérez-Liñán, 2013). Political parties are the key actors in a democratic system (Aldrich, 2011). In his classical work, Richard S. Katz (1980, p.1) notes that the "character of the parties in a political system is intimately related to the quality of its democracy", and correspondingly, Ziblatt (2017) demonstrates that it was the strategic decisions of (conservative) parties that sealed the fate of democracy in the Interwar years. Here we focus on the characteristics of political parties in the current period, recognizing that when a strong leader is present her/his identity will naturally shape the identity of the party.

The paper first discusses which traits of political parties are related to autocratization and develop the argument for anti-pluralism. Second, we introduce the V-Party data set and the rel-

\footnotetext{
1 Based on this argument, Levitsky and Ziblatt, 2018 later developed a list of early-warning indicators for potential
} anti-democratic behaviour. 
evant measures of party characteristics. Third, we demonstrate a strong relationship between between levels of anti-pluralism in parties and autocratization if they come into power, before finally concluding.

\section{Populism, ideology, or anti-pluralism}

Some 35 years after the 1974 Carnation revolution in Portugal started the "third wave of democratization", Putin rose to Prime Minister in president Yeltsin's democratically elected administration on $16^{\text {th }}$ August 1999 . He was soon duly elected president (26 ${ }^{\text {th }}$ March 2000 ) with $53 \%$ of the vote in relatively free and fair elections. Although none of us knew it at the time, the "third wave of autocratization" (Lührmann and Lindberg, 2019) was getting underway. As a marker of what was going to come, the democratization process in Portugal's famous revolution started off with a military coup, while the autocratization in Russia took off with a democratic election.

The ensuing descent into an electoral autocracy in Russia foretold a feature characterizing the present: Democratically elected parties and their leaders emasculate democratic norms and institutions to curtail competition to stay in power (e.g. Boese et al., 2020; Cassani and Tomini, 2018; Diamond, 2020; Haggard and Kaufman, 2016; Levitsky and Way, 2015; Norris and Inglehart, 2019; Plattner, 2015). This differs from most autocratization processes in the $20^{\text {th }}$ century that originated in unconstitutional changes such as military coups, foreign interventions, and autogolpes (Bermeo, 2016).

A recent study of the past 120 years shows that when a party seeking to derail democracy comes into power and autocratization gets on its way, there is only about a $20 \%$ chance to avoid breakdown (Boese et al., 2020). It is therefore critical to identify the traits of political parties that erode democracy once they come into power. That would enable both an "early warning system" and open up for studying such parties before they take power to seek explanations why they gain ground, or not. It would also be instrumental for international democracy support community as a tool in democracy protection activities.

\section{Signifiers of political parties that derail democracy}

We find three sets of arguments in the literature on the traits signifying parties and their leaders that derail democracy if they come into power. Some scholars argue that populism is the main culprit (e.g. Mudde, 2004; Müller, 2017), while a second group suggests that qualities associated with certain ideologies - for instance far-right or far-left — are the identifiers (e.g. Eatwell and Mudde, 2003; Levitsky and Roberts, 2011). The third strand focuses on the commitment of political leaders and parties to democratic norms and thus their degree of "illiberalism" or anti-pluralism (e.g. Pappas, 2016; Zakaria, 1997). While there is some conceptual overlaps and the three are therefore not completely mutually exclusive, we argue that neither the core attributes of populism nor of those of ideologies are the most important signifiers of parties and leaders that undermine 
democracy once in power. Rather, we concur that lacking commitment to democratic norms as such - anti-pluralism is the best predictor of autocratization.

\section{Populism}

Pundits sometimes equate populism explicitly with authoritarian leanings (e.g. Galston, 2017; Müller, 2017; Plattner, 2010). ${ }^{2}$ Müller (2017) suggests that the populist claim of representing 'the people' is always a threat to democracy. Others see populism as a threat to democracy because they connect it to corruption, the suppression of a critical civil society, and an exclusionary division of peoples into 'us' and 'them' (e.g. Galston, 2018). Yet, scholars have attributed populism to various political parties that claim to represent ordinary people's $v s$ the elites. They usually agree on three core ideas as characteristic of populism: people-centrism, anti-elitism, and an antagonism between the "virtuous people" and the "corrupt elite" (e.g. Hawkins, 2010; Mudde, 2004; Rooduijn, 2014). ${ }^{3}$

Based on such thin definitions, populism as such is not necessarily antidemocratic (see also Pappas, 2016) since not all leaders of populist parties seek to repress individual liberal rights and freedoms. In empirical analyses some researchers therefore distinguish between populist rhetoric and antidemocratic traits. For example, Norris and Inglehart (2019, p.4, 7) make a distinction between populism as an anti-elitist rhetoric, and authoritarianism as denying "liberal autonomy for the individual". Similarly, Rydgren (2017) opposes generalizing all new extreme-right parties as "populist", and Akkerman (2003) finds that only populist parties that press for radical reform to benefit a popular majority are a threat, while populists who respect institutional pluralism are not. Populist parties can be progressive, conservative, socialist, authoritarian, or other in the twodimensional economic-GALTAN space (Akkerman and Rooduijn, 2015; Norris and Inglehart, 2019, p.4).

We agree that it makes sense to distinguish populist rhetoric from commitment to democratic norms. Populism is defined by anti-elitist and people-centric rhetoric, predicated on a view of the "good" people and the "evil elite" (Hawkins, 2009). This is at the core of populist rhetoric and the common denominator of most scholarly definitions of populism (e.g. Akkerman, 2003; Hawkins, 2009; Mudde, 2004; Müller, 2017; Norris and Inglehart, 2019; Rooduijn, 2014, p.543). While populist rhetoric might correlate somewhat with autocratization, populism as such is not necessarily incongruent with commitment to democratic norms.

2 See also Cas Mudde and Jan-Werner Müller in Uri Friedman's article in the Atlantic: https://www. theatlantic.com/international/archive/2017/02/what-is-populist-trump/516525/ And Kurt Weyland in the Washington Post: https://www.washingtonpost.com/news/monkey-cage/wp/2017/08/11/ there-are-4-big-barriers-to-the-the-populist-model-in-america-and-your-democracy-is-safe/

$3 \quad$ Mudde and Kaltwasser (2013, p. 150-151) — the protagonists of this ideational approach to populism, define it as follows: "Populism is a thin-centered ideology (...) with three core concepts : the pure people (depicted as a homogeneous and virtuous community), the corrupt elite (seen as a homogeneous but pathological entity) and the general will (idea that all individuals of a given community are able to unify their wills with the aim of proclaiming popular sovereignty as the only legitimate source of political power)." Similarly, Norris and Inglehart (2019, p.66) view populism as a "claiming that (i) the only legitimate democratic authority flows directly from the people, and (ii) established powerholders are deeply corrupt and self-interested, betraying public trust" 


\section{Ideology}

Political idelogy is an alternative suggestion to what threatens democracy (Akkerman, 2003; Mudde and Kaltwasser, 2013, p.38): Parties holding extreme opinions and advocating extreme measures, located farthest from the political centre that are juxtaposed to "normal" parties and thus suggesting severely radical policies. Two dimensions of party systems are used to identify extreme political ideologies. The classic left-right dimension and the more recent progressive-traditional dimension, or the GALTAN scale.

On the traditional left-right scale, focusing on economic policy, one argument is that the extreme-left is a threat to democracy by virtue of its fervor for state interventionism that facilitates incumbent hegemony (Schamis, 2006; Weyland, 2013). One find such instances of chief executives implementing redistributive policies while eroding democratic norms (e.g.Ecuador, Bolivia, and Venezuela) (Levitsky and Roberts, 2011, p.399). Historically, also extreme-right, conservative parties opposed democracy but we have not found empirical studies suggesting that current parties with far-right economic policies are likely to erode democracy.

There is also the GALTAN dimension, meaning that Green, Alternative, and Libertarian parties are located on the progressive side, while Traditional, Authoritarian, and Nationalist parties are on the other side of the spectrum (Bakker et al., 2015; Hooghe, Marks, and Wilson, 2002; Marks et al., 2006; Rohrschneider and Whitefield, 2009). Progressives favor expanding personal freedoms, believe the government should not interfere in people's personal decisions, and oppose discrimination against minorities such as LGBTI, racial and ethnic groups, and others. Traditionalists see the government as a moral authority that should guarantee order, favor traditional values above unbridled freedom, and value the national community often associated with a religious affiliation (Hooghe, Marks, and Wilson, 2002). The threat to democracy is expected from from ideologies of the far-right traditionalists. For example, using a pooled cross-sectional design and data from 30 European countries from 1990 to 2012, Huber and Schimpf (2017) show that traditionalist right-wing parties have negative effects on minority rights, and it is argued that such parties are associated with the propagation of violence and racism, which is detrimental for democratic stability (Koopmans, 1996).

Yet it seems to us that that political extremes may pave the way for, yet is not equal to an "at all costs" approaches that becomes more dangerous to democracy the more convinced its supporters get. With data on over 1,700 powerful political actors in 20 Latin American countries over a span of 66 years, Mainwaring and Pérez-Liñán (2013) show that privileging policy goals over process among powerful political actors is a key factor for democratic survival. They conclude that "competitive regimes are highly vulnerable to breakdown if the most powerful actors are indifferent to liberal democracy's intrinsic value" (Mainwaring and Pérez-Liñán, 2013, p.135). Also ideologically relatively moderate parties can be a danger to democracy if and when the goal is considered more important than the means. The key is that when ideology beats adhering to process and norms, democracy is at risk. Recent experimental work shows that citizens who feel represented 
by the executive are more willing to delegate the president more authority even at the expense of democratic principles, and the magnitude of the effect increases with partisan attachment (McCoy, Simonovits, and Littvay, 2020; Singer, 2018; Svolik, 2018).

Arguably, political ideology on either the classic or the cultural dimension may lead to democratic decay if, and only if, political actors and voters place their ideological interests above democratic norms. It is less ideology at the extremes as such than prioritizing goals over democratic norms that is the key factor. Therefore, we turn to the third approach.

\section{Anti-pluralism}

Building on the reasoning above and insights by Linz (1978), Levitsky and Ziblatt (2018) and Müller (2012), it becomes clear that future autocratizers are signified by lacking commitment to democratic institutions, procedures, and norms. However until now, we lacked a robust conceptualization, data, and systematic empirical tests of which traits identify future autocratizers before they come to power.

The term illiberalism recently gained prominence in part due to its frequent use by Prime Minister Orbán in Hungary, who declared that he wants to transform his country into an "illiberal democracy". 4 Among others, scholars like Zakaria, 1997 and Pappas (2016, p. 31) use "illiberalism" to denote a system of government that holds multiparty elections but does not protect basic liberties, and "illiberals" for the parties and leaders seeking to derail democracy. But these terms suffer from frequent misinterpretations and thus the risk of a collective conceptual confusion. "Liberal" with its Latin root lïberälis has many meanings, from negative connotations of unrestrained by prudence, to open-mindedness; broad-based education favoring independent thinking; state noninterventionism in the economic sphere and beyond; favoring of social or even socialist reforms; and designated political parties with varying agendas.

Instead, consider that most relevant definitions of democracy rest on the foundation of pluralism in the full sense of the word (Dahl, 1971), which goes far beyond simplistic understandings of a mere plurality of parties or interest groups. As discussed for example by Sartori, 1997, pluralism is a value system itself positing not only tolerance but also respect for opposing views on the basis of mutual reciprocity. The limits to tolerance is only harm to the principle of tolerance itself, as in Popper's words: "tolerate[s] all who are prepared to reciprocate, i.e.who are tolerant" (Popper, 1945, p. 293). Pluralism thus requires consensus about the principles of reciprocal tolerance, which in effect makes democracy not "the peaceful resolution of conflict" but rather makes disagreements something less than conflict. Pluralism and its principle of tolerance also informs the democratic principle that while the majority may rule, its legitimate course of actions are limited-they must respect the rights of minorities. Thus, pluralism embraces "that societies are composed of several social groups with different ideas and interests." (Mudde and Kaltwasser, 2013, p. 152).

Several authors (Mudde and Kaltwasser, 2013; Müller, 2017; Norris and Inglehart, 2019, p.51)

$4 \quad$ Orbán in July 2014 as quoted by Plattner $(2019$, p. 9). 
view pluralism as the opposite pole of populism, yet anti-pluralism does not feature in their definitions of populism. That seems to be like removing the active ingredient. In scholars' and in the everyday sense of "populism", it does not necessarily include anti-pluralism. For analytical clarity, it is therefore critical to separate the two terms.

Anti-pluralism has four key characteristics. The first one is unwillingness to commit to the democratic process as legal means for gaining power. Dahl (1971) formulated the minimum requirements in terms of institutional guarantees safeguarding true pluralism in competition among political parties for power, and enabling orderly alternations. When parties do not commit to respect for these institutions regulating the means to access power, it signals anti-pluralism.

The second attribute is denial of the legitimacy of dissenting parties and opponents. This follows directly from the principle of reciprocal tolerance on which pluralism rests. This is well exemplified by John McCain's remarks during the 2008 presidential campaign about his political rival Barack Obama: "He's a decent family man, a citizen that I just happen to have disagreements with on fundamental issues, and that's what this campaign is all about." ${ }^{5}$ If political actors instead delegitimize, severely personally attack, or demonize their opponents, it is an indication of lacking commitment to pluralism (Levitsky and Ziblatt, 2018, p.23-24). This includes dehumanizing opponents or describing them as an existential threat, subversive, criminal, or foreign agents. The only exception is that one may legitimately deny the rightful existence of parties that do not sign on to the consensus of the principle of pluralims itself. Popper (1945, p.130) pointed to this in his work on the paradox of freedom. If freedom includes the right to abolish itself, citizens are prohibited from exercising democratic freeddoms in the future. Parties are endorsing pluralism only as long as they are committed to the same democratic processes, institutions, and freedoms that made pluralism possible in the first place. Consequently, anti-pluralist democracy is an oxymoron.

The third key feature is toleration or endorsement of the use of political violence. Pluralism is predicated on that disagreements with political opponents should be solved according to the agreed rules and procedures (Sánchez-Cuenca, 2003, p. 69). One of the key components of the rule of law is the principle that the law protects civil liberties from arbitrary violation by the state even if elected representatives would agree to such infringements (Merkel, 2004, p. 39). Thus, a key indication for a weak commitment to the rule of law is support for the notion that the will of the majority should be implemented even if doing so would violate the physical integrity of opponents. In the extreme, this entails the threat or use of political violence. Thus, toleration or endorsement of the use of political violence is a clear signal of an anti-pluralist party or leader (Levitsky and Ziblatt, 2018, p. 23-24).

Finally, indications that a party and its leaders could consider curtailing the civil liberties of minority groups is a clear signal of anti-pluralists. Dahl (1971) and others rightly emphasize that democracy requires not only choice in elections, also a plurality of information and opinions that can be expressed freely. Civil liberties enable pluralism by providing the individual with the rights to life, liberty, and economic activity but also by assuring citizens the opportunity to express themselves,

https://time.com/4866404/john-mccain-barack-obama-arab-cancer/ 
associate with others, assemble, protest, and be informed by varying viewpoints. Civil liberties are fundamental prerequisites for pluralism. To illustrate this point, consider the following "chain of democratic choice". ${ }^{6}$ If citizens are unable to express themselves others cannot learn about their preferences. Even if their preferences are known, if citizens are not allowed to form organizations their preferences are not aggregated and amplified at the societal level. Even if a variety of associations is permitted, if the media is either not willing or not permitted to report on them citizens are not presented with the existing plurality of options. Thus, without civil liberties citizens do not have a real choice on election day, and we do not know if their vote or opinion polls reflects actual preferences. A system in which the people's preferences are not known, cannot be described as being 'ruled by the people' and hence is not democratic. Thus, if pluralism is severely undermined in any piece of the democratic chain it breaks, and no meaningful democracy exist.

We submit that these are four key issues where anti-pluralist parties may reveal themselves to be likely autocratizers if and when they come into government. Anti-pluralist parties lack commitment to $i$ ) the democratic process as the legal means of gaining and losing power; ii) the legitimacy of political opponents; iii) peaceful resolution of disagreements and rejection of political violence; and iv) unequivocal support for civil liberties of minorities. We define those political parties as to a varying degree anti-pluralist that register lack of commitment in these areas.

\section{The litmus test identifying anti-pluralists}

The reasoning above coheres with Linz's (1978, p.\& 29) famous "litmus test" of what characterizes political actors disloyal to the democratic system (see Table 1). Levitsky and Ziblatt (2018) build on Linz's work and argue that one can identify challengers to democracy by examining their public statements before they come to office. They provide a list of four indicators that are very similar to Linz's original catalogue: 1) A weak commitment to democratic rules of the game; 2) The denial of the legitimacy of political opponents; (3) The toleration or encouragement of violence; and (4) A readiness to curtail civil liberties. They also detail further specifics of instances that fall under each category. Müller (2012) suggests in a similar fashion that dispension by parties and their leaders of each of the following four political positions, constitutes an attack on "core democratic principles" and in effect are anti-pluralist: (1) Exclusion of groups of citizens; (2) denial of the "dignity" of groups of citizens; (3) positive identification with past "ethnic cleansing or genocide"; and (4) denial of pluralist society by claiming to "speak in the name of the people as a whole" ${ }^{7}$. His four items map well onto the previous ones but are more narrowly focused.

What remains is how these four indicators could be measured. When considering suitable indicators we must be cognizant that anti-pluralist parties typically seek to shore up their credentials as "regular democratic parties" in official party documents. For example, data from the Manifesto Project (Volkens et al., 2019) show that such parties routinely pay lip service to democracy as the "only game in town". The German far-right party AfD scores high (4.08) and the center-right

See Schedler (2002, pp. 39-41) for the development of similar notion focusing on election quality.

Müller (2012, p. 1287). 
Table 1: Indicators of anti-pluralist political actors

\begin{tabular}{|c|c|c|}
\hline Linz (1978) & Levitsky and Ziblatt (2018) & Lührmann et al. (2020) \\
\hline $\begin{array}{l}\text { Unwillingness to } \\
\text { publicly commit to } \\
\text { legal means for } \\
\text { gaining power }\end{array}$ & $\begin{array}{l}\text { Expresses willingness/need to } \\
\text { violate the constitution; } \\
\text { Expresses sympathy for } \\
\text { non-constitutional } \\
\text { means of accessing power; } \\
\text { Attempts to undermine } \\
\text { the legitimacy of elections }\end{array}$ & $\begin{array}{l}\text { Low commitment to } \\
\text { the democratic process }\end{array}$ \\
\hline $\begin{array}{l}\text { Denial of the legitimacy } \\
\text { of democratic political } \\
\text { parties to participate in } \\
\text { political processes }\end{array}$ & $\begin{array}{l}\text { Describes rivals as subversive, } \\
\text { criminal, or foreign agents; } \\
\text { Claims that rivals constitute } \\
\text { existential threat }\end{array}$ & $\begin{array}{l}\text { Demonization of } \\
\text { political opponents }\end{array}$ \\
\hline $\begin{array}{l}\text { No rejection of } \\
\text { the use of force; } \\
\text { Willingness to ask for } \\
\text { the armed forces }\end{array}$ & $\begin{array}{l}\text { Has ties to armed gangs or militias; } \\
\text { Sponsors or encourages mob } \\
\text { attacks on opponents; Endorses } \\
\text { or praises political violence }\end{array}$ & $\begin{array}{l}\text { Encouragement of } \\
\text { political violence }\end{array}$ \\
\hline $\begin{array}{l}\text { Curtailment of the civil } \\
\text { liberties of democratic } \\
\text { parties' leaders and } \\
\text { supporters }\end{array}$ & $\begin{array}{l}\text { Supports laws or policies } \\
\text { restricting civil liberties; } \\
\text { Threatens to take legal action } \\
\text { against critics; Praises repression }\end{array}$ & $\begin{array}{l}\text { Disrespect for } \\
\text { fundamental } \\
\text { minority rights }\end{array}$ \\
\hline
\end{tabular}

Source: Levitsky and Ziblatt (2018), Linz (1978), and Lührmann, Düpont, et al. (2020)

party CDU low (0.74) on their measure counting the favorable mentions of democracy in the party manifestos. Using public party documents is therefore not likely to create a valid measure.

But rhetoric in campaign speeches and other events directed at party supporters and others can be more authentic and revealing (Maerz and Schneider, 2021). Maerz and Schneider (2019) compared 4,740 speeches from heads of government in 27 countries between 1999 and 2019, and found that leaders in autocratic countries use a substantially less democratic style of rhetoric than leaders of democratic countries. Linz (1978) found that political parties later seeking to break down democracy, are typically explicit with their true anti-pluralism while they are still not in influential positions. Once their appeal expands to a broader audience, they are likely to "convey equivocal messages in order to maintain their radical opposition to the system while claiming to aim at a legal access to power" (Linz, 1978, p. 29). Thus, we should expect such parties to come with increasingly vague anti-pluralist assertions until they accede to power and then embark on a path of autocratization (Levitsky and Ziblatt, 2018). There are exceptions such as Fidesz's rhetoric during their 2010 return to government shows. ${ }^{8}$ Even so, it is important to have sensitive

$\overline{8}$ https://www. economist.com/eastern-approaches/2010/07/04/read-the-large-print 
measures capturing even if some actors openly display only a mild anti-pluralist tendency.

But relaying on speech data from party leaders' public appearances would be limiting since not all campaigns were covered equally extensively. Coverage is going to be biased towards more developed countries with large media infrastructures, as well as towards later years when more and more materials are available for these techniques. So while studies like Maerz and Schneider (2019) are informative in terms of contemporary analysis and for hypothesis-generation, the data is less useful for the purposes here.

We therefore turn to the new, unique V-Party data set (Lührmann, Düpont, et al., 2020) building on V-Dem's gold-standard methodology for multiple expert-based ratings (Coppedge et al., 2020; Pemstein et al., 2020). A selection of V-Party's indicators were designed to capture Linz's lithmus-test and therefore fit for the purposes here:

- Low commitment to the democratic process (v2paplur): "Prior to this election, to what extent was the leadership of this political party clearly committed to free and fair elections with multiple parties, freedom of speech, media, assembly and association?"

- Demonization of political opponents (v2paopresp): "Prior to this election, have leaders of this party used severe personal attacks or tactics of demonization against their opponents?"

- Disrespect for fundamental minority rights (v2paminor): "According to the leadership of this party, how often should the will of the majority be implemented even if doing so would violate the rights of minorities?"

- Encouragement of political violence (v2paviol): "To what extent does the leadership of this party explicitly discourage the use of violence against domestic political opponents?"10

\section{Data and descriptive empirical analysis}

The V-Party dataset was constructed by 665 purposefully selected country experts assessing the identity of all political parties with a vote share of more than $5 \%$ in a legislative election between 1970 and 2019 in their country of expertise, across 169 countries. The dataset covers 1,943 political parties across 1,759 elections-or in total 6,321 party-election year units. Typically at least 4 experts contributed to each question. ${ }^{11}$ All items are measured on a five-point ordinal scale and aggregated to latent, interval measures while correcting for possible between-expert differences in scale use, using V-Dem's custom-designed IRT model (Pemstein et al., 2020). We have rescaled

\footnotetext{
$9 \quad$ Coder were shown the following clarification: "This concerns the rights enshrined in the Universal Declaration of Human Rights, which apply to everyone 'without distinction of any kind, such as race, colour, sex, language, religion, political or other opinion, national or social origin, property, birth or other status.' The declaration protects - among others - freedom of speech, property, religion, peaceful assembly and association.”

10 Coders were shown the following clarification: “'Domestic political opponents' refers to all political opponents, with the exception of those who are engaged in an armed conflict with the state. They may be other political parties or other political groups and movements." (Lührmann, Düpont, et al., 2020)

$11 \quad$ Mean $=4.55 ;$ median $\left(\mathrm{p}_{50}\right)=4 ; \mathrm{p}_{25}=3 ; \mathrm{p}_{10}=2$.
} 
the variables here so that high values indicate a high level of anti-pluralism. For details see appendix A.

\section{Index aggregation}

We aggregate the four discussed indicators to the Anti-Pluralism Index (API). They do not capture equally severe violations of democratic processes, institutions, and norms. In particular, an explicit denial of democratic institutions and processes such as elections is a more severe rejection of pluralism than harsh language towards opponents. The first one captures an openly authoritarian trait whereas the latter one might also express a contentious political culture. Based on this reasoning, we compute the index as a transformed weighted average of the input indicators using the following formula:

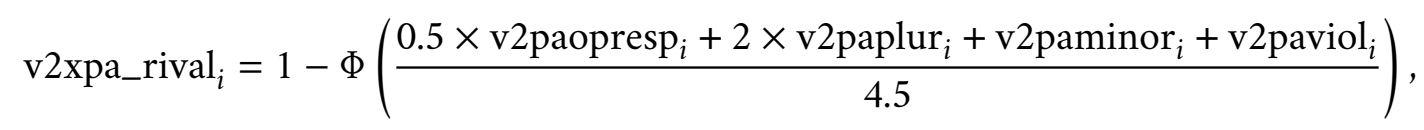

where $i$ indexes observations, $\Phi$ is the standard normal cumulative density function, and the four indicators are Demonizing opponents (v2paopresp), Low commitment to democratic processes (v2paplur), Disrespect for fundamental minority rights (v2paminor), and Encouragement of political violence (v2paviol). Figure B.1 in the Appendix shows the joint distributions of the API and its components.

\section{Data validation and descriptive analysis}

It is usual to asses all three forms convergence, content, and construct validity for a new measure (Adcock and Collier, 2001). Since no other measure has yet captured the anti-pluralist traits of political parties, we assess convergent validity by comparing the values on the Anti-Pluralism Index of ruling parties in democracies (top of Figure 1) with the one in autocracies (bottom). Reassuringly, this shows a stark difference between ruling parties in these two regime categories. In democracies, the smoothed median score in 2019 was 0.28 and in autocracies much higher with 0.85 . The time trend is also informative. The median governing party in democracies has become more anti-pluralist in recent decades, with the smoothed median score rising from 0.08 in 1970 to 0.28 in 2019, which is congruent with research showing that contemporary threats to democracy typically come from within the government (Bermeo, 2016). The median governing party in autocracies has become somewhat less anti-pluralist in the same period, reflecting the mimicking of multi-party elections in most autocracies (Schedler, 2002). This finding thus supports the not only the convergence but also the content validity of the new index.

To further assess the content validity of the API, we explore some relevant cases. Figure 2 shows the movement of the US Republican and Democratic parties in this century on two dimensions: anti-pluralism and left-right positioning on economic policy, with other parties positioning at the last election in relief. The Republican party has not changed left-right placement but moved 
Figure 1: Anti-Pluralism Index (API) of governing parties. Parties that gained or retained the Head of Government post in national elections. The lines with $95 \%$ regions estimated with a quantile GAM with Gaussian Process over days. Elections split by regime (v2x_regime): autocracies $\{0,1\}$, democracies $\{2,3\}$. Color by economic left-right on the OSP scale: left $[0,2]$, center $(2,4]$, right $(4,6]$.

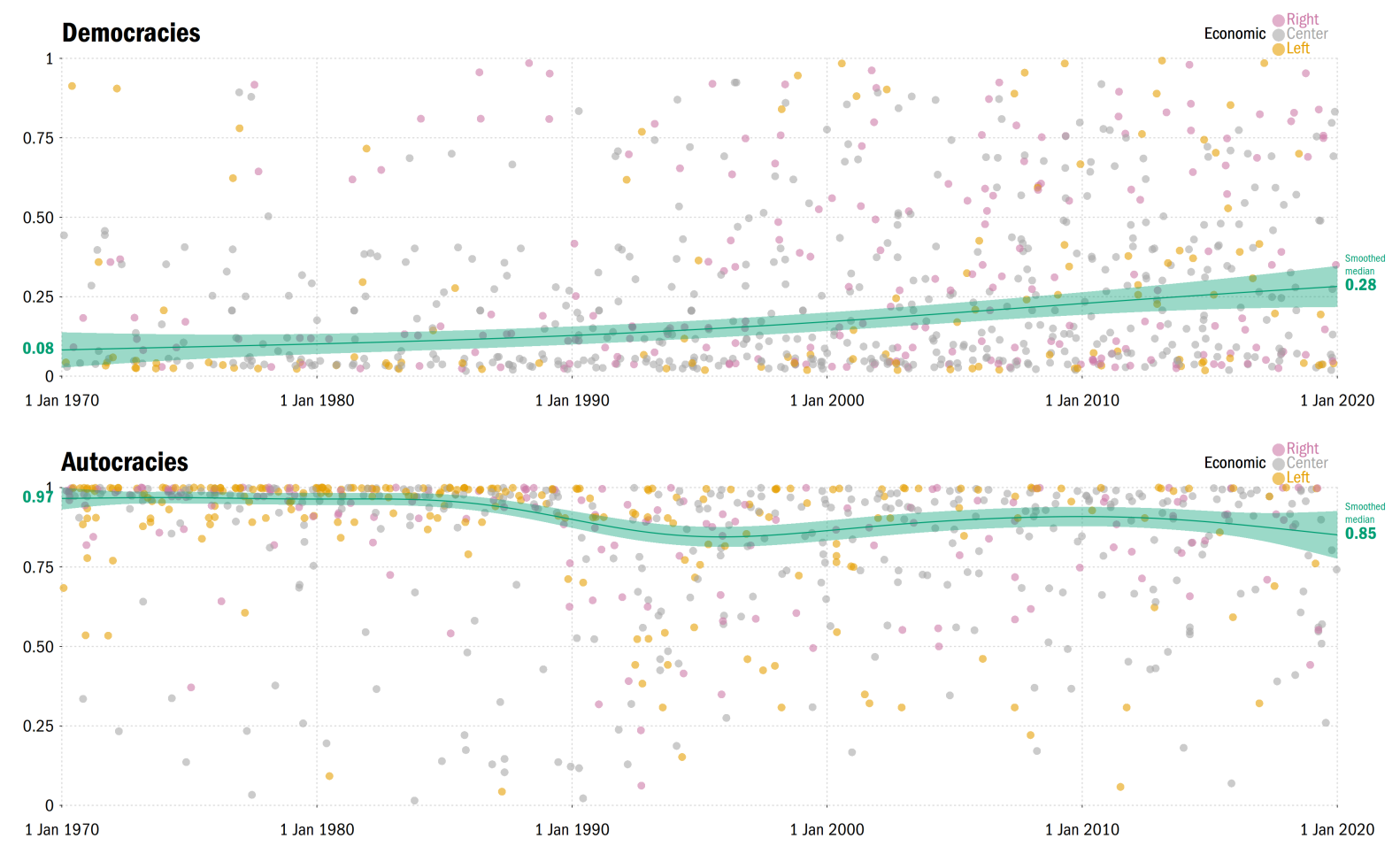

strongly in an anti-pluralist direction with a score on the API of 0.69. This reflects that Trump in his 2016 presidential campaign made personal, demonizing attacks on political opponents leading to a high score of 0.86 on the indicator on demonization of the opponent (see Table 2). ${ }^{12}$ He also condoned violence towards his political opponents, saying about Clinton that "If she gets to pick her judges, nothing you can do, folks [...] Although—the second amendment people-maybe there is, I don't know", ${ }^{13}$ and towards protesters at his rallies, saying things like "I loved the old days, you know what they used to do to guys like that when they were in a place like this? They'd be carried out on a stretcher, folks and even offering to relieve the consequences of political violence: "[...]knock the crap out of them, would you? [...] I will pay for the legal fees, I promise". ${ }^{14}$ This is reflected in a high

12 https://www. theguardian.com/us-news/2016/may/25/donald-trump-crooked-hillary-clintonnickname-ignore-fight

https://www. theguardian.com/us-news/video/2016/aug/12/donald-trump-hillary-clinton-daywrong-florida-video

https://abcnews.go.com/Politics/crooked-hillary-marco-donald-trumps-nicknames/story?id= 39035114

13 https://www. theguardian.com/us-news/2016/aug/09/trump-gun-owners-clinton-judges-secondamendment

https://www.bbc.com/news/election-us-2016-37036856 The second amendment to the Bill of Rights in the constitution of the United States of America has long been subject to controversial debate and guarantees that "...the right of the people to keep and bear Arms, shall not be infringed" https://www.constituteproject.org/constitution/United_States_of_America_1992?lang=en.

14 https://www. theguardian.com/us-news/video/2016/feb/23/donald-trump-says-hed-like-to-punchprotester-at-nevada-rally-video 
score for the encouragement of violence (0.35, Table 2). From the Democratic party no similar statements are known.

Figure 2: The movements of the two major US parties on the Anti-Pluralism Index and economic left-right since 2000.

1.0

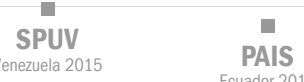

AKP

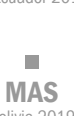

$\stackrel{+}{\stackrel{+}{\text { Autocracies }}}$

PSL
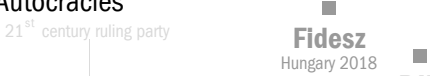

0.8

Pis

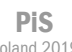

Republicans

20162018

0.6

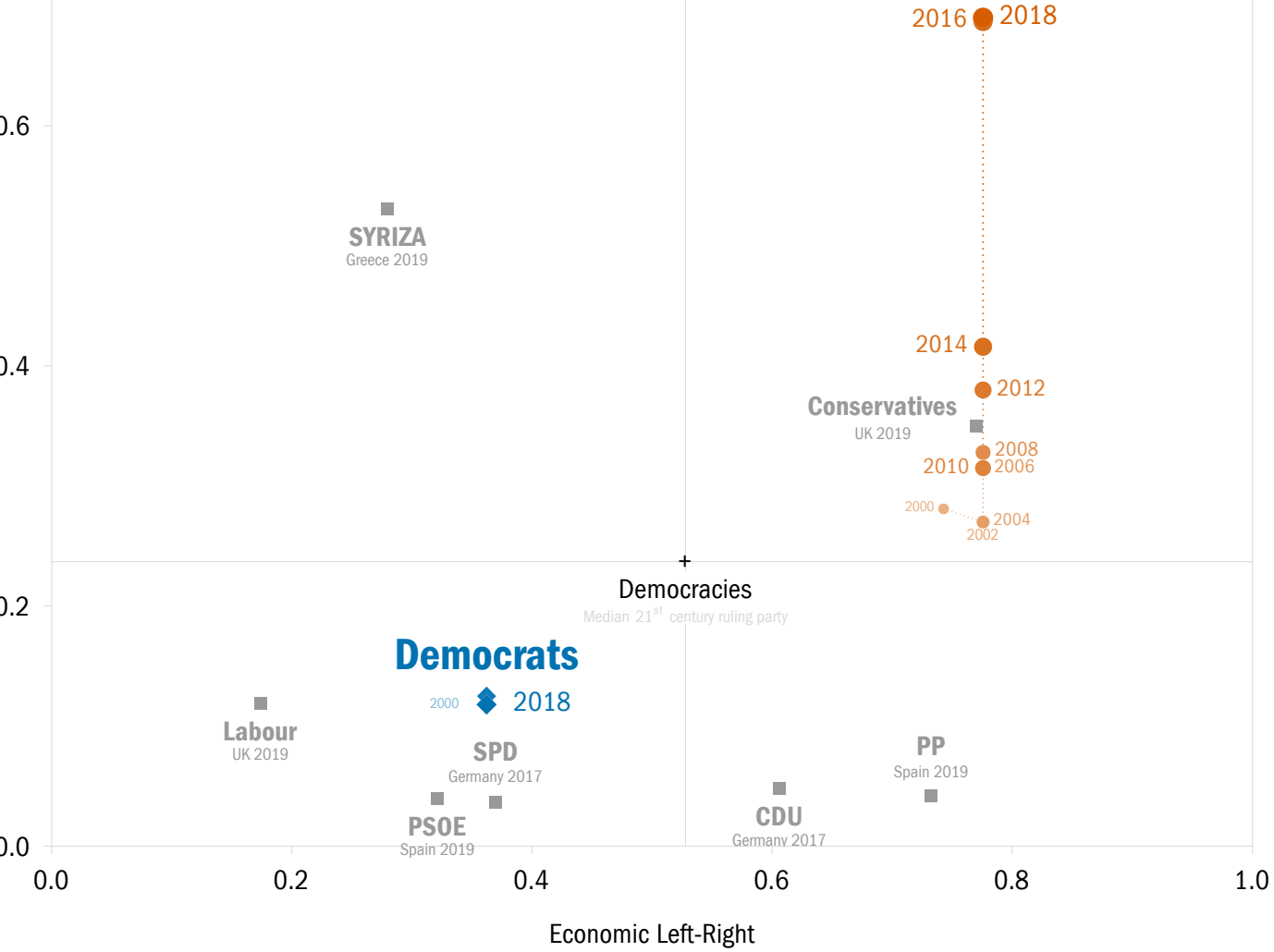

0.2

By 2016, the rhetoric of the Republican party was in the sense more similar to autocratic ruling parties such as the Turkish AKP (1.0) and Hungarian Fidesz (0.88) than to typical center-right governing parties in democracies such as the Conservatives in the UK (0.35) or CDU in Germany (0.05). This also applies to Bolsonaro (PSL, Brazil) whose rhetoric during the 2018 presidential campaign was filled with demonization of the opposition and violence promotion (Hunter and Power, 2019). During a campaign event, while pretending to hold a riffle, he told supporters: "Let's shoot the Workers' Party supporters", which his campaign later dismissed as a joke. ${ }^{15}$ After a wave of violence against minorities carried by his supporters, Bolsonaro commented "What has that

https://www.bbc.com/news/election-us-2016-35793103

15 https://www.nytimes.com/2018/10/17/world/americas/brazil-attacks-bolsonaro-haddad.html 
got to do with me?". ${ }^{16}$ These positions are reflected on PSL's score of 0.95 on the API. Likewise, PiS, the ruling-party in Poland since 2015, had a high API of 0.80 at the 2019 elections reflecting for instance that the government-controlled media attacked and demonized PiS' opponents and accused them of threatening traditional Polish values (Markowski, 2020). A more drastic example is the Turkish AKP, which receieved the highest possible score of 1.0 ahead of the 2018 elections reflecting that not only the party used anti-pluralist rhetoric, but also that the AKP-controlled government interfered with the campaign, jailing political opponents and controlling access to national television. ${ }^{17}$

The Greek SYRIZA is on an intermediary level in terms of anti-pluralism with an overall score of 0.53 ahead of the 2015 election. Their overall discourse was inclusionary, upholding human rights, which resulted in low scores on commitment to the democratic process (0.18). However, similarly to other populist parties in Europe, SYRIZA criticized opponents of being subservient to foreign powers and the international banking system (Aslanidis and Rovira Kaltwasser, 2016; Font, Graziano, and Tsakatika, 2021; Lisi, Llamazares, and Tsakatika, 2019) and, thus, did not perform well on demonization of political opponents (0.60). Similarly, the Conservative Party in the UK has moved somewhat towards anti-pluralism due to severe instances of demonization of the opposition during the 2019 electoral campaign reflected in a high API score of 0.35. However, overall they are still in the pluralistic spectrum. ${ }^{18}$ From the leadership of Angela Merkel's CDU no anti-pluralistic statements or behavior is known, which corresponds to a low score on the API of 0.05 in 2017.

Table 2: Scores of selected parties on the Anti-Pluralism Index and its component indicators. Indicators have reversed scales to range from 0 (pluralist) to 1 (anti-pluralist).

\begin{tabular}{llcccccc}
\hline & & & & \multicolumn{3}{c}{ API Component Indicators } \\
\cline { 5 - 8 } Party & Country & Election & $\begin{array}{l}\text { Anti- } \\
\text { Pluralism } \\
\text { Index }\end{array}$ & $\begin{array}{l}\text { Demo- } \\
\text { cratic } \\
\text { Process }\end{array}$ & $\begin{array}{l}\text { Demo- } \\
\text { nization }\end{array}$ & $\begin{array}{l}\text { Disrespect Encourage- } \\
\text { minori- } \\
\text { ties }\end{array}$ & $\begin{array}{l}\text { ment of } \\
\text { Violence }\end{array}$ \\
\hline AKP $^{a}$ & Turkey & 2018 & 1 & 0.96 & 0.99 & 0.93 & 0.95 \\
PSL & Brazil & 2018 & 0.95 & 0.53 & 0.91 & 0.88 & 0.53 \\
Fidesz & Hungary & 2018 & 0.88 & 0.41 & 0.96 & 0.79 & 0.38 \\
PiS & Poland & 2019 & 0.80 & 0.35 & 0.91 & 0.71 & 0.37 \\
Republicans & USA & 2016 & 0.69 & 0.28 & 0.86 & 0.61 & 0.35 \\
SYRIZA & Greece & 2015 & 0.53 & 0.18 & 0.60 & 0.49 & 0.52 \\
Conservatives & UK & 2019 & 0.35 & 0.09 & 0.87 & 0.82 & 0.04 \\
Democrats & USA & 2016 & 0.13 & 0.13 & 0.37 & 0.31 & 0.02 \\
CDU & Germany & 2017 & 0.05 & 0.05 & 0.15 & 0.27 & 0.04 \\
\hline
\end{tabular}

In 2018 the AKP ran as part of the People's Alliance.

\footnotetext{
16 https://www. theguardian.com/world/2018/oct/11/brazil-election-violence-bolsonaro-haddad

17 https://www.nytimes.com/2018/06/22/world/europe/turkey-elections-erdogan-opposition. html

18 https://www.independent.co.uk/news/uk/politics/conservative-social-media-strategy-attackjeremy-corbyn-labouir-twitter-facebook-video-stormzy-akala-jme-a7784406.html
} 


\section{Anti-pluralism in action: autocratization after winning power}

The idea here is that identifying anti-pluralism among parties before the come into power is indication that they will pursue a path of autocratization if and when they rule. This notion rests on the assumption that future autocratizers tend to reveal their lacking commitment to democratic norms before taking power in speech acts. That parties that are inherently anti-pluralist would be expected to undermine democratic pluralism if and when they assume power, should be uncontroversial. The question is if the Anti-Pluralist Index can capture that in advance, and the extent to which anti-pluralism in parties is a driver of autocratization.

In order to test these ideas about the relationship between the characteristics of political parties rhetoric before, and the behavior of political leaders after assuming office, we conduct descriptive analysis and run regressions on a subgroup of 771 cases: Political parties, which hold the office of Head of Government after a given election in a democracy. ${ }^{19}$ As we detail above, these ideas reflected longstanding hypotheses, which have not been susceptible to empirical testing due to lack of data. Thus, our analysis here are both relevant for their own sake as well as an exercise of construct validation (Adcock and Collier, 2001). But first we introduce how we measure autocratization.

\section{Operationalizing autocratization}

Our dependent variable is binary, taking the value of 1 if the country is undergoing substantial autocratization in the year after the elections and 0 if it is not. This is based on autocratization episodes identified by Edgell et al. (2020). Such autocratization represents a decline in V-Dem's Electoral Democracy Index (EDI) of more than 10\% of the index value during one year or over a connected time period. Operationalizing autocratization in this way is superior to a simple yearto-year change as it allows us to capture substantial and gradual processes of autocratization, while at the same time not registering year-to-year fluctuations that may be do measurement noise.

We focus on autocratization led by elected incumbents as the most common mode of contemporary autocratization - in contrast to autocratization starting with an illegal power grab such as military coups or international invasion. In prior research, instances of such incumbent-led autocratization have been termed "autogolpes" (Przeworski et al., 2000, p. 21), but here we also include the more gradual forms. We identified whether each autocratization episode was led by an elected leader or not using a range of qualitative data sources as well as Powell and Thyne (2011) and Coppedge et al. (2020).

19 To identify which party is in power we use an updated version of the variable v2pagovsup from Lührmann, Düpont, et al. (2020). To identify democracies we use the variable v2x_regime in the year before elections from Coppedge et al. (2020). 


\section{Descriptive analysis of the relationship between anti-pluralist ruling par- ties and autocratization}

When anti-pluralist parties are in power in democracies $29 \%$ autocratize in the year after they won (or defended) the office of the Head of Government (see Group IV on Table 3). ${ }^{20}$ Conversely, after pluralists win office, only 6\% of democracies autocratize (Group II) while most remain as democratic as they were before (94\%; Group I). This is a much less likely outcome after the election of anti-pluralists (71\%; Group III). The large Group I (democratic stability with pluralists governing) is not much of a surprise as one would expect pluralists to rule in a democracy. However, all other groups require further scrutiny.

Table 3: Anti-pluralists winning elections in democracies and autocratization $(t+1), 1970-2018$.

\begin{tabular}{l|c|c|c}
\hline & No autocratization & \multicolumn{1}{|c|}{ Autocratization } & \\
\hline $\begin{array}{l}\text { Pluralists } \\
\text { in power }\end{array}$ & $\begin{array}{l}\text { I: Democratic stability with plu- } \\
\text { ralists governing }\end{array}$ & $\begin{array}{l}\text { II: Autocratization with plural- } \\
\text { ists governing }\end{array}$ & \\
\hline $\begin{array}{l}\text { Anti- } \\
\text { pluralists } \\
\text { in power }\end{array}$ & $\begin{array}{l}\text { III: Democratic stability with } \\
\text { anti-pluralists governing }\end{array}$ & $\begin{array}{l}\text { IV: Autocratization with anti- } \\
\text { pluralists governing }\end{array}$ & $193(100 \%)$ \\
\hline All & $679(88 \%)$ & $92(12 \%)$ & 771 \\
\hline
\end{tabular}

The center line in Figure 3 illustrates the relationship between anti-pluralism in ruling parties (x-axis) and the level of electoral democracy in their countries (y-axis). It shows that, typically, the more anti-pluralist ruling parties become, the lower the level of democracy. Political parties to the right of the vertical line (at the API value of 0.429) are considered as anti-pluralists here and the lines in color illustrate the trajectories of selected Group IV parties. The Polish Law and Justice Party (PiS), the Hungarian Fidesz Party and the Turkish Justice and Development Party (AKP) have started in this millennium with a score in the pluralist party spectrum. The Indian Bharatiya Janata Party (BJP) exhibited already in 1999 some level of anti-pluralism. However, over the course of the last 20 years, all four parties have become more and more anti-pluralists. Under their leadership, their countries have also becoming increasingly autocratic, with Hungary losing its status as democracy in 2018 and Turkey in 2014.

The Justice and Development Party (AKP) increased its anti-pluralist traits between every election since its foundation. When Erdoğan came to power after the 2002 election, he had promised reforms that would enhance the separation of powers, the independence of the judiciary, increase the freedom of press, and strengthen the rule of law. However, Erdoğan's increasingly anti-pluralist actions continued to break his promises. Over the years, he has continuously showcased highly anti-pluralist behavior such as cracking down on protesters and accusing them of

$20 \quad$ Parties scoring more than 0.429 on the API are considered here as anti-pluralist. This is the above the 75 th percentile for governing parties in democracies in our sample. 
Figure 3: Anti-pluralism of governing parties in election years and V-Dem's Electoral Democracy Index in the first post-election year $(t+1)$.

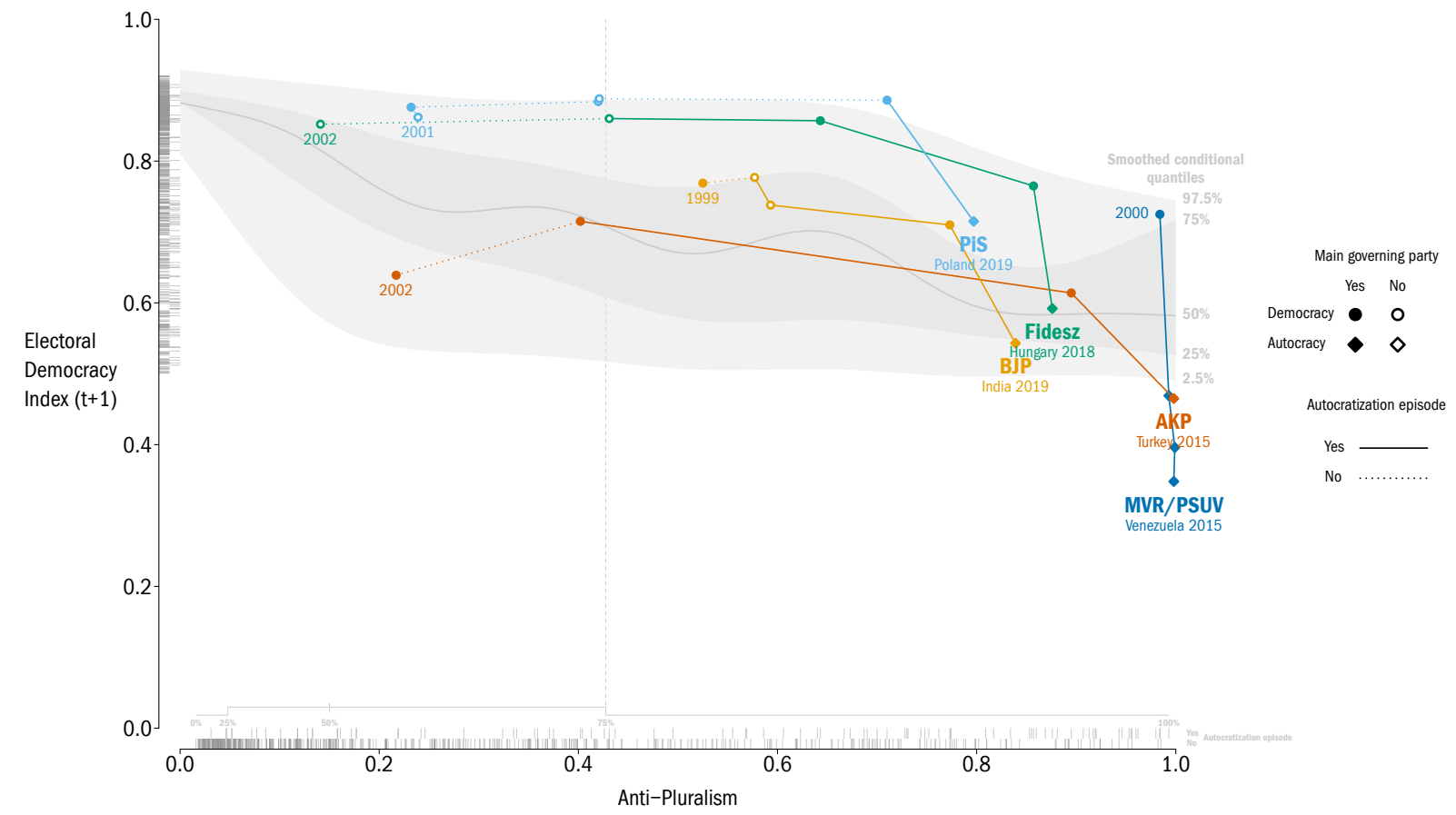

attempting to destabilize the country (Taspinar, 2014), orchestrating prosecutions of political opponents, and describing the separation of powers as "an obstacle" that he would overcome by hollowing out the judiciary (Karaveli, 2016).

The Polish Polish Law and Order's (PiS) became gradually more anti-pluralistic throughout the years, going from an API score of 0.23 in 2005, when it was first elected governing party, to 0.71 when they returned to that position in 2015 . This increase resulted from of a change to emphasizing nationalism, disrespecting fundamental minority rights, and demonizing opponents (Harper, 2010, p. 24). Additionally, PiS has undermined the independence of the judiciary, checks and balances, as well as freedom of expression (Markowski, 2020). This has led Poland's EDI score to decline from 0.87 in 2014 to 0.72 in 2019.

In a similar turn of events, Hungary scored well on the EDI prior to the 2010 election, when Fidesz won the elections. The Orbán government has since placed constrains on civil society and restricted freedom of expression as well as academic freedom, passing legislation that led to the closing of the Central European University in Budapest. ${ }^{21}$ Additionally, Orbán blatantly demonizes the opposition. ${ }^{22}$ Thus, there has been a significant decline in EDI, with scores declining from 0.54 in 2014 to 0.32 by the time new elections were held in 2018.

The MVR/PSUV in Venezuela have consistently scored high on anti-pluralism with a score of 0.95 already in 1998, when Chávez won his first election. Venezuela then embarked on a drastic autocratization episodes with EDI scores dropping from 0.78 in 1999 to 0.35 by 2015 . After Mauduro succeeded Chávez, PSUV was defeated in the 2015 legislative elections. In response,

21 https://www.ceu.edu/istandwithceu/timeline-events

22 https://www.nytimes.com/2018/04/07/world/europe/hungary-viktor-orban-election.html 
Maduro stripped the parliament of power and designated the Supreme Court to take over the functions of the National Assembly. By consolidating the power in the executive branch, controlling public institutions, and censoring and persecuting the opposition, PSUV has managed to stay in power for over two decades. (Alarcón, Álvarez, and Hidalgo, 2016; Corrales, 2020)

The Hindu-nationalist BJP became India's governing party in 2014 led by Narendra Modi. Democracy has deteriorated since then, with EDI scores declining from 0.71 to 0.54 between the 2014 and 2019 parliamentary elections. A series of policies have diminished freedom of expression and academic freedom, and repression of civil society has increased. BJP's vision of India as a Hindu nation has also led to persistent discrimination against Muslims (Ganguly, 2020; Maerz, Lührmann, et al., 2020; Varshney, 2019). This is reflected in BJP's 0.84 score on the API in 2019.

However, not all countries autocratize with anti-pluralists in office (Group III). In 137 cases, autocratization has not started in the year after an anti-pluralist was in power (lower rug on the right of Figure 3). The median API in that group is with 0.68 lower than in the group where anti-pluralism is followed by autocratization ( 0.77 , Group IV). This may indicate that a certain threshold is required for autocratization to be the consequences, which is an issue for future research. A similar argument might apply for the level of liberal constraints on the executive which are with a median score of 0.73 higher in Group III than in the autocratizing group IV $(0.66){ }^{23}$ Parliamentary and judicial oversight as well as the rule of law may help to prevent autocratization. ${ }^{24}$ A moderately anti-pluralist party that did not substantially erode democracy when ruling is the Italian Forza Italia with an anti-pluralism score of 0.72 in 2001. Silvio Berlusconi ruled Italy from 2001 to 2006 and from 2008 to 2011, and while he was known for anti-pluralist verbal provocations, the Italian institutions remained more or less intact (Verbeek and Zaslove, 2016).

A few elections (36) have been followed by autocratization even though a pluralist party was in office (Group II). In some a party used pluralist rhetoric while eroding democracy. For example, Citizens for European Development of Bulgaria (GERB) scored 0.13 on the API when gaining power in 2009. Yet, the quality of democratic institutions declined in Bulgaria from 2009 to 2019, as indicated by shift on the EDI from 0.72 to 0.59 (Maerz, Lührmann, et al., 2020, pp. 10-13). GERB has persued an agenda of state capture by putting loyal individuals in charge over media outlets, the Supreme Justice Council, and anti-corruption agencies providing de-facto impunity to top party members (Ganev, 2018). A similar but less pronounced autocratization process occurred in Chile under pluralist leadership from 2011 to $2019,{ }^{25}$ and in Israel (2010 to 2019). ${ }^{26}$ In other cases, the pluralist party leader wining the elections was removed from office under dubious circumstances as with President Dilma Rousseff in Brazil in 2016 (Chalhoub et al., 2017). Finally, there are cases in this group registering only minor democratic declines under pluralist rule but more severe declines happen later under anti-pluralist rule, for instance in Hungary in 2007 and the United

\footnotetext{
$23 \quad$ Based on the Liberal Component Index at $t-1$ from Coppedge et al. (2020).

24 For a similar argument see Boese et al. (2020).

25 https://rsf.org/en/news/rsf-alarmed-escalating-violence-against-reporters-chile

26 https://foreignpolicy.com/2010/03/10/civil-society-and-human-rights-in-israel-andelsewhere/
} 
States in 2015.

The discussion here illustrates the construct and convergent validity of out measures. First, the developments on the anti-pluralism index correspond to real-life events. Second, it captures anti-pluralist traits of ruling parties before they begin eroding democracy. Third, the data is nuanced enough to show development over time; i.e.to not judge a party in 2000 by what it did later in the century. Fourth, they also show that the measures of autocratization and anti-pluralist rhetoric capture distinct concepts.

\section{Regression analysis: research design}

We investigate the relationships between autocratization episodes and senior government party characteristics with regression models. Our data contains 771 parties that have gained or defended the Head of Government post in an election in 104 democracies from 1970 until 2018. To capture possible nonlinearities, we use Generalized Additive Models (GAM) under which party characteristics as well as additional covariates are included via Gaussian Process (GP) smooths (see e.g. Hastie and Tibshirani, 1990). Under a binary $y$-variable, the Gaussian GAM is a more flexible counterpart of the popular Linear Probability Model (see e.g. Angrist and Pischke, 2008), and the smooths may be interpreted analogically to slopes under the LPM.

\section{Additional party characteristics}

As discussed above, there are also other party characteristics that influence both the propensity of parties to take anti-pluralist positions as well as their inclination to commit autocratization. We therefore include measures from the V-Party data set (Lührmann, Düpont, et al., 2020) on three party characteristics. First, we adjust for a thin version of populist rhetoric, which captures the extent to which parties use anti-elitist rhetoric and "glorify the ordinary people and identify themselves as part of them” (Lührmann, Düpont, et al., 2020, p.26). This index is aggregated using the harmonic mean, in order to allow for some substitutability between the input indexes, but only to a limited degree. ${ }^{27}$ Second, research shows that political ideology associates with undemocratic behaviour, following an U-shape under which the incidence of undemocratic behavior is higher on both extremes than in the middle. ${ }^{28}$ Therefore, we adjust for the traditional, or economic left-right dimension of the party system. ${ }^{29}$ Third, we capture the distinction between progressive and conservative parties with an index on cultural characteristics, which aggregates measures on immigration (v2paimmig), LGBT Social equality (v2palgbt), Cultural superiority (v2paculsup),

A more detailed discussion is available in the Appendix.

See discussion above.

Experts were asked to "locate the party in terms of its overall ideological stance on economic issues" on a 0 (far-left) to 6 (far-right) scale. They were shown the following clarification: "Parties on the economic left want government to play an active role in the economy. This includes higher taxes, more regulation and government spending and a more generous welfare state. Parties on the economic right emphasize a reduced economic role for government: privatization, lower taxes, less regulation, less government spending, and a leaner welfare state” (Lührmann, Düpont, et al., 2020). 
religious principles (v2parelig), and working women (v2pawomlab). For more details on these measures see Appendix A. When used in regressions, all party characteristics are scaled from 0 (left/non-populist) to 1 (right/populist).

\section{Contextual covariates}

To adjust for the socio-economic and political context in the pre-election year $(t-1)$ we include the following covariates. First, since the likelihood of autocratization as well as the election of anti-pluralist parties might vary with the level of liberal constraints in a democracy, we include V-Dem's Liberal Component Index (LCI) (Coppedge et al., 2020). It captures both legislative and judicial constraints on the executive, and the rule of law. Democracies are said to be more likely to break down if they have a presidential system (Linz, 1978; Svolik, 2008). Thus, we adjust for presidential systems using V-Dem data. ${ }^{30}$

Second, both the rise of parties which challenge democracy as well as autocratization is observed more frequently in weak economies (Przeworski et al., 2000) and during economic crises (Bernhard, Nordstrom, and Reenock, 2001). Democratic regime's failure to combat economic crises in a way satisfactory to the citizens reduces the legitimacy of the incumbent regime and democracy, and thus increases the risk of autocratization following an economic crisis. This is especially true in countries with a background of poor economic performance, a lower level of development, or a relatively short democratic history (Haggard and Kaufman, 2016; Møller, 2018; Waldner and Lust, 2018 p. 323-324). Therefore, we adjust for GDP/capita (natural logarithm) and GDP growth/capita using data from the Maddison project ${ }^{31}$. An equal distribution of resources reduces the likelihood of autocratization (e.g. Diamond, 2015; Haggard and Kaufman, 2016; Leininger, Lührmann, and Sigman, 2019; Tomini and Wagemann, 2018). Therefore, we adjust for inequality with V-Dem's Equal Distribution of Resources Index, which measures the extent to which resources are equally distributed in a society.

Finally, it seems plausible that autocratization becomes more likely in a global climate of many reverse trends and less likely in a context of democratization (Lührmann and Lindberg, 2019). Therefore, we adjust for the share of countries going through autocratization and democratization episodes each year. ${ }^{32}$ For similar reasons, we adjust for the average regional EDI, always excluding the country of observation from the average (Coppedge et al., 2020). We also include year to account for temporal effects and allow for non-linear relationship with a GP smooth.

\footnotetext{
30 It captures if the chief executive is unitary (v2exhoshog=1) and directly elected by the population (v2expathhs=7) (Teorell and Lindberg, 2015).

31 As included in Coppedge et al. (2020)

32 This measure was created by dividing the total number of autocratization and democratization episodes by the total number of countries per year (Maerz, Edgell, et al., 2021).
} 


\section{Regression analysis: results}

Figure 4 gives estimated conditional relationships between autocratization and the four components of anti-pluralism. Each estimate comes from a separate model that conditions on all the contextual covariates described above. The Y-axis shows the expected change in the probability of autocratization and the $\mathrm{X}$-axis the values of the component. We report additional model specifications in the Appendix, all of which give substantively similar estimates unless noted otherwise here.

Figure 4: Modeled Probability of Autocratization in the Year after Election (Indicator-level). Partial effects under Gaussian identity-link GAMs with GP smooths $(N=771)$. Each model includes the plotted index and adjusts for the same set of contextual coviariates (see above). Upper rugs show observations with autocratization at $t+1$, lower rugs observations without it. 2016 US Republicans highlighted with a longer orange tick. Shaded $\pm 1 \mathrm{SE}$ and $\pm 2 \mathrm{SE}$ regions.
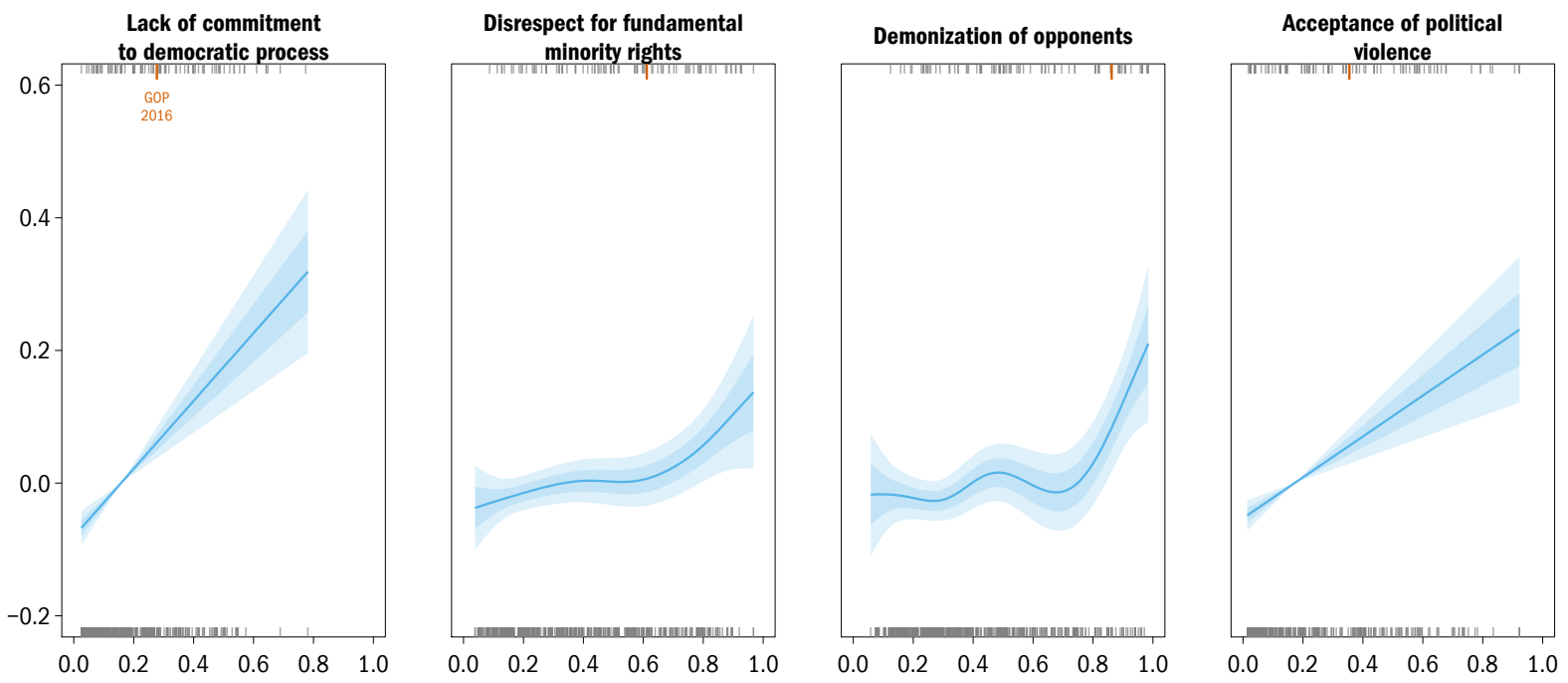

Weak commitment to the democratic process is associated with a substantially greater modeled probability of autocratization. This relationship is substantively and statistically significant starting already at relatively minor deviations from the democratic baseline (" $t \mathrm{t}]$ he party leadership was fully committed to free and fair, multi-party elections, freedom of speech, media, assembly and association"). We find a similar relationship to autocratization for acceptance of political violence. This association weakens if the other three party attributes (populism, cultural dimension and economic left-right) are included in the model specification (see Figure C.10 in the Appendix). Disrespect for minority rights has a similar, but weaker relationship to autocratization. However, this relationship disappears if the other three party attributes are included in the model specification (see Table C.10 in the Appendix).

What is the substantive implication of these findings? For the litmus test to work, what matters most are pairwise associations of each characteristic with autocratization. This is what we clearly find for all four characteristics, whether we adjust for contextual covariates or not. In short, the socio-economic and political context does not seem to alter the picture. However, when considering the four at the same time, it seems that lacking commitment to democratic process and accepting political violence are the most telling ones (Figure C.9 in the Appendix). Also extreme 
levels of demonization of opponents seems to associate with a higher probability of autocratization in a given context.

Another perspective is available by considering the capacity to predict autocratization. We quantify it by Area Under the receiver operator Curve (AUC), which has a straightforward interpretation as the proportion of all possible $\left\{y_{k}=0, y_{k^{\prime}}=1\right\}$ observation pairs in which the latter has a larger predicted value of $\left(p_{k}<p_{k^{\prime}}\right)$. We estimate AUC with leave-pair-out cross validation (Airola et al., 2009), by sampling 10 thousand $\left\{y_{k}=0, y_{k^{\prime}}=1\right\}$ observation pairs. A detailed summary features in Table C.1 in the Appendix. Lack of commitment to democratic process and acceptance of political violence already on their own achieve a fair predictive performance, with AUCs of 0.77 , and adding all contextual covariates increases the AUCs only somewhat, to 0.83 .

Figure 5: Modeled Probability of Autocratization in the Year after Election (Index-level) Partial effects under four Gaussian identity-link GAMs $(N=771)$. Each model includes the plotted index and adjusts for the same set of coviariates. Upper rugs show observations with autocratization at $t+1$, lower rugs observations without it. 2016 US Republicans highlighted with a longer orange tick. Shaded \pm 1 SE and \pm 2 SE regions.
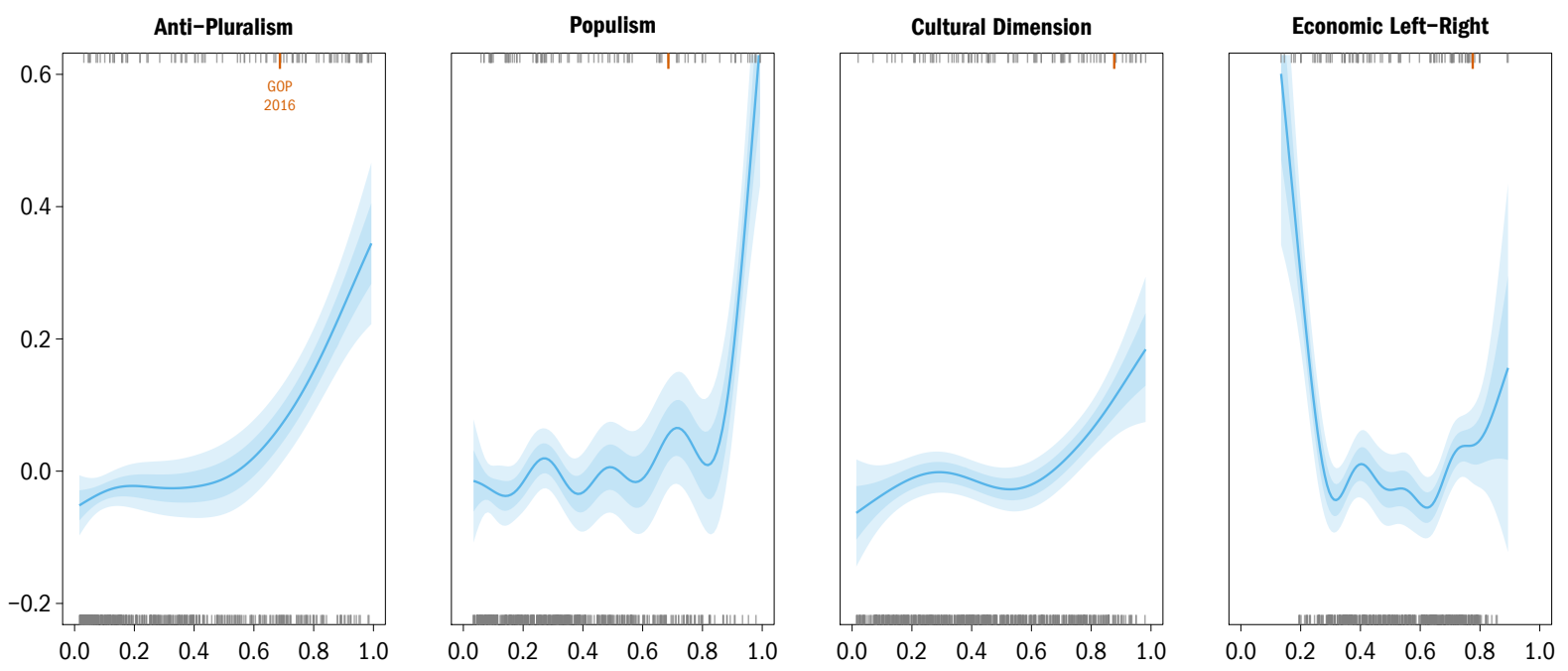

Figure 5 shows the estimated relationships with autocratization of the Anti-Pluralism Index (API) and additional party characteristics under models that include socio-economic and political covariates. A greater level of anti-pluralism is associated with a greater modeled probability of autocratization. This relationship is substantially and statistically significant at high levels of antipluralism. For populist attributes some relationship to autocratization can be found; but only for very high levels of populism, for which we do not have many observations in the sample. For culturally far-right parties we find a positive relationship to autocratization onset as expected. In terms of economic party positions only extreme far-left victorious parties are associated with a statistically significant greater probability of autocratization.

Predictive model performance as captured by AUC-LPOCV, reported in detail in Table C.1 in the Appendix, is better for the anti-pluralism either with (0.83) or without (0.79) the contextual covariates. Populism, the cultural dimension, and economic left-right score is at $0.66,0.61$, and 0.62 without and at $0.82,0.81$, and 0.83 with the covariates. In short, the API on its own predicts autocratization nearly as well as any of the other indexes combined with contextual covariates. 
To assess the sensitivity of our findings, we reanalysed our data under alternative model specifications and operationalizations of the autocratization variable. In the Appendix, we report several additional analyses:

- We estimate the same Gaussian GAMs as above using two alternative operationalizations of the autocratization variable, namely autocratization episode at the second and at the third post-election year. Figures C.9, C.10, C.11, and C.12 report the estimates. All lead to the same substantive conclusions as the main analysis above.

- We reanalyse the data with Binomial-probit GLMs. Tables C.2 and C.3, report the estimates. Again, these support the same substantive findings.

- Finally, we operationalize the autocratization variable with changes in the Revised Polity (Marshall, Gurr, and Jaggers, 2016) score between the last pre-election year and the first postelection year, and analyse the data with Gaussian linear regressions (OLS). Tables C.4 and C. 5 report the estimates. For the party variables of interest, the point estimates are largely of the same direction and relative magnitude as in the main analysis. However, their associated standard errors are relatively large. This does not surprise as this operationalization measures incumbent-led autocratization at lower precision than our main approach. ${ }^{33}$

\section{Conclusions}

What characterizes the parties and leaders that lead autocratization processes once in power? They lack commitment to democratic norms and processes, encourage violence, and demonize opponents. The answer to that question might seem trivial to some given Linz' lithmus test Linz (1978) and Levitsky and Ziblatt (2018) influential list of early-warning indicators. However, this paper first disentangles the concept of anti-pluralism from popular notions of populism and ideology, thus extracting the operative elements characterizing parties that constitute a threat to current democracies. The paper then provides an operationalization of these, and details new unique indicators for the four critical aspects.

Our empirical analysis is the first to show that parties characterized by scoring high on these indicators, are indeed "walking the talk" and their anti-pluralist rhetoric prior to becoming an elected governing party should be taken seriously. The tests presented are possible due to new data from the V-Party data set on the anti-pluralist traits of all 771 parties that won power in democracies between 1970-2018 (Lührmann, Düpont, et al., 2020) and new data identifying autocratization (Edgell et al., 2020).

The fine-grained expert-coded data allows us to differentiate between Head of Governments that autocratize after after coming to power using anti-pluralist rhetoric, and those that did not. For instance, Bulgaria autocratized under the leadership of Boyko Borisov from 2009 to 2019, but

\footnotetext{
33 It not only measures autocratization, but also democratization and captures minor fluctuations in democracy ratings.
} 
the V-Party data does not indicate anti-pluralistic rhetoric in the lead-up to the 2009 elections. ${ }^{34}$ However, as our results show, when a candidate for executive office does use anti-pluralist rhetoric before the election, they are more likely to autocratize after assuming office. Although not all autocratizers provide such a warning, most do. To safeguard liberal democracy, it is important to be alert for these early warning signals.

This study points at what kind of rhetoric provides such signals. Scholars - and also concerned citizens - should be alert when a candidate doubts democratic norms, encourages violence and disrespects opponents. Future research should examine both the factors that lead to such anti-pluralists reaching power as well as the constraining factors, which might avert democratic breakdown even though an anti-pluralist is in power.

\section{References}

Adcock, R. and Collier, D., 2001. Measurement validity: a shared standard for qualitative and quantitative research. American Political Science Review, pp.529-546.

Airola, A., Pahikkala, T., Waegeman, W., De Baets, B., and Salakoski, T., 2009. A comparison of AUC estimators in small-sample studies. Machine Learning in Systems Biology. PMLR, pp.3-13.

Akkerman, T., 2003. Populism and democracy: challenge or pathology? Acta Politica, 38(2), pp.147-159.

Akkerman, T. and Rooduijn, M., 2015. Pariahs or partners? Inclusion and exclusion of radical right parties and the effects on their policy positions. Political Studies, 63(5), pp.1140-1157.

Alarcón, B., Álvarez, Á.E., and Hidalgo, M., 2016. Latin America's new turbulence: can democracy win in Venezuela? Journal of Democracy, 27(2), pp.20-34.

Aldrich, J.H., 2011. Why parties? A second look. University of Chicago Press.

Angrist, J.D. and Pischke, J., 2008. Mostly harmless econometrics: an empiricist's companion. Princeton University Press.

Aslanidis, P. and Rovira Kaltwasser, C., 2016. Dealing with populists in government: the SYRIZA-ANEL coalition in Greece. Democratization, 23(6), pp.1077-1091.

Bakker, R., De Vries, C., Edwards, E., Hooghe, L., Jolly, S., Marks, G., Polk, J., Rovny, J., Steenbergen, M., and Vachudova, M.A., 2015. Measuring party positions in Europe: The Chapel Hill expert survey trend file, 1999-2010. Party Politics, 21(1), pp.143-152.

Bermeo, N., 2003. Ordinary people in extraordinary times: the citizenry and the breakdown of democracy. Princeton University Press.

Bermeo, N., 2016. On democratic backsliding. Journal of Democracy, 27(1), pp.5-19.

Bernhard, M., Nordstrom, T., and Reenock, C., 2001. Economic performance, institutional intermediation, and democratic survival. Journal of Politics, 63(3), pp.775-803.

Boese, V.A., Edgell, A.B., Hellmeier, S., Maerz, S.F., and Lindberg, S.I., 2020. Deterring dictatorship: explaining democratic resilience since 1900. V-Dem Working Paper, 101.

$34 \quad$ Case studies support this assessment of Boyko Borisov's rhetoric as not undemocratic or anti-law, but perhaps somewhat populist (Ganev, 2018; Ghodsee, 2008). Still, Bulgaria did autocratize during his time as Prime Minister, and his actions have proven substantially more anti-plural than his rhetoric, as he for example represses freedom of expression and controls the media environment (Ganev, 2018). 
Cassani, A. and Tomini, L., 2018. Reversing regimes and concepts: from democratization to autocratization. European Political Science, pp.1-16.

Chalhoub, S., Collins, C., Llanos, M., Pachón, M., and Perry, K.-K.Y., 2017. Report of the LASA fact-finding delegation on the impeachment of Brazilian president Dilma Rousseff. Latin American Studies Association.

Coppedge, M., Gerring, J., Knutsen, C.H., Lindberg, S.I., Teorell, J., Altman, D., Bernhard, M., Fish, M.S., Glynn, A., Hicken, A., et al., 2020. V-Dem Codebook v10.

Corrales, J., 2020. Authoritarian survival: why Maduro hasn't fallen. Journal of Democracy, 31(3), pp.39-53.

Dahl, R., 1971. Polyarchy: Participation and opposition. Yale University Press.

Diamond, L., 2015. Facing up to the democratic recession. Journal of Democracy, 26(1), pp.141-155.

Diamond, L., 2020. Democratic regression in comparative perspective: scope, methods, and causes. Democratization, pp.1-21.

Eatwell, R. and Mudde, C., 2003. Western democracies and the new extreme right challenge. Routledge.

Edgell, A.B., Wilson, M.C., Boese, V.A., and Grahn, S., 2020. Democratic legacies: using democratic stock to assess norms, growth, and regime trajectories. V-Dem Working Paper, 100.

Font, N., Graziano, P., and Tsakatika, M., 2021. Varieties of inclusionary populism? SYRIZA, Podemos and the Five Star Movement. Government and Opposition, 56(1), pp.163-183.

Galston, W.A., 2017. Anti-pluralism: the populist threat to liberal democracy. Yale University Press.

Galston, W.A., 2018. The populist challenge to liberal democracy. Journal of Democracy, 29(2), pp.5-19.

Ganev, V.I., 2018. Explaining Eastern Europe: “soft decisionism” in Bulgaria. Journal of Democracy, 29(3), pp.91-103.

Ganguly, S., 2020. An illiberal India? Journal of Democracy, 31(1), pp.193-202.

Ghodsee, K., 2008. Left wing, right wing, everything: Xenophobia, neo-totalitarianism, and populist politics in Bulgaria. Problems of Post-Communism, 55(3), pp.26-39.

Haggard, S. and Kaufman, R.R., 2016. Dictators and democrats: masses, elites, and regime change. Princeton University Press.

Harper, J., 2010. Negating negation: Civic Platform, Law and Justice, and the struggle over "Polishness". Problems of Post-Communism, 57(4), pp.16-36.

Hastie, T.J. and Tibshirani, R.J., 1990. Generalized additive models. CRC press.

Hawkins, K.A., 2009. Is Chávez populist? Measuring populist discourse in comparative perspective. Comparative Political Studies, 42(8), pp.1040-1067.

Hawkins, K.A., 2010. Venezuela's Chavismo and populism in comparative perspective. Cambridge University Press.

Hooghe, L., Marks, G., and Wilson, C.J., 2002. Does left/right structure party positions on European integration? Comparative Political Studies, 35(8), pp.965-989.

Huber, R.A. and Schimpf, C.H., 2017. On the distinct effects of left-wing and right-wing populism on democratic quality. Politics and Governance, 5(4), pp.146-165.

Hunter, W. and Power, T.J., 2019. Bolsonaro and Brazil's illiberal backlash. Journal of Democracy, 30(1), pp.68-82.

Karaveli, H., 2016. Erdogan's journey: Conservatism and authoritarianism in Turkey. Foreign Affairs, 95(6), pp.121-130. 
Katz, R.S., 1980. A theory of parties and electoral systems. The John Hopkins University Press.

Koopmans, R., 1996. Explaining the rise of racist and extreme right violence in Western Europe: Grievances or opportunities? European Journal of Political Research, 30(2), pp.185-216.

Leininger, J., Lührmann, A., and Sigman, R., 2019. The relevance of social policies for democracy: preventing autocratisation through synergies between SDG 10 and SDG 16, 7/2019. Discussion Paper.

Levitsky, S. and Roberts, K.M., 2011. The resurgence of the Latin American left. JHU Press.

Levitsky, S. and Way, L., 2015. The myth of democratic recession. Journal of Democracy, 26(1), pp.45-58.

Levitsky, S. and Ziblatt, D., 2018. How democracies die. Broadway Books.

Linz, J.J., 1978. Crisis, breakdown ef reequilibration. Johns Hopkins University Press.

Lisi, M., Llamazares, I., and Tsakatika, M., 2019. Economic crisis and the variety of populist response: evidence from Greece, Portugal and Spain. West European Politics, 42(6), pp.1284-1309.

Lührmann, A., Düpont, N., Higashijima, M., Kavasoglu, Y.B., Marquardt, K.L., Bernhard, M., Döring, H., Hicken, A., Laebens, M., Lindberg, S.I., Medzihorsky, J., et al., 2020. Codebook Varieties of Party Identity and Organization (V-Party).

Lührmann, A., Gastaldi, L., Hirndorf, D., and Lindberg, S.I., 2020. Defending democracy against illiberal challengers - A resource guide. Varieties of Democracy Institute/University of Gothenburg.

Lührmann, A. and Lindberg, S.I., 2019. A third wave of autocratization is here: what is new about it? Democratization, 26(7), pp.1095-1113.

Maerz, S.F., Edgell, A.B., Wilson, M.C., Hellmeier, S., and Lindberg, S.I., 2021. A framework for understanding regime transformation: introducing the ERT dataset. V-Dem Working Paper, 113.

Maerz, S.F., Lührmann, A., Hellmeier, S., Grahn, S., and Lindberg, S.I., 2020. State of the world 2019: autocratization surges-resistance grows. Democratization, 27(6), pp.909-927.

Maerz, S.F. and Schneider, C.Q., 2019. Comparing public communication in democracies and autocracies: automated text analyses of speeches by heads of government. Quality er Quantity, pp.1-29.

Maerz, S.F. and Schneider, C.Q., 2021. Public discourse and autocratization: infringing on autonomy, sabotaging accountability. V-Dem Working Paper, (112).

Mainwaring, S. and Pérez-Liñán, A., 2013. Democracies and dictatorships in Latin America: Emergence, survival, and fall. Cambridge University Press.

Markowski, R., 2020. Plurality support for democratic decay: the 2019 Polish parliamentary election. West European Politics, 43(7), pp.1513-1525.

Marks, G., Hooghe, L., Nelson, M., and Edwards, E., 2006. Party competition and European integration in the East and West: different structure, same causality. Comparative Political Studies, 39(2), pp.155-175.

Marshall, M.G., Gurr, T.R., and Jaggers, K., 2016. Polity iv project: political regime characteristics and transitions, 1800-2015. Center for systemic peace, 13.

McCoy, J., Simonovits, G., and Littvay, L., 2020. Democratic hypocrisy: Polarized citizens support democracy-eroding behavior when their own party is in power. APSA Preprints.

Merkel, W., 2004. Embedded and defective democracies. Democratization, 11(5), pp.33-58.

Møller, J., 2018. Resilient democracies. American Interest. 
Mudde, C., 2004. The populist zeitgeist. Government and Opposition, 39(4), pp.541-563.

Mudde, C. and Kaltwasser, C.R., 2013. Exclusionary vs.inclusionary populism: Comparing contemporary Europe and Latin America. Government and Opposition, 48(2), pp.147-174.

Müller, J.-W., 2012. Militant democracy. The Oxford handbook of comparative constitutional law, 1253, p.1261.

Müller, J.-W., 2017. What is populism? Penguin UK.

Norris, P. and Inglehart, R., 2019. Cultural backlash: Trump, Brexit, and authoritarian populism. Cambridge University Press.

Pappas, T.S., 2016. The specter haunting Europe: Distinguishing liberal democracy's challengers. Journal of Democracy, 27(4), pp.22-36.

Pemstein, D., Marquardt, K.L., Tzelgov, E., Wang, Y.-t., Medzihorsky, J., Krusell, J., Miri, F., and Roemer, J. von, 2020. The V-Dem measurement model: latent variable analysis for cross-national and cross-temporal expert-coded data. V-Dem Working Paper, 21.

Plattner, M.F., 2010. Democracys past and future: populism, pluralism, and liberal democracy. Journal of Democracy, 21(1), pp.81-92.

Plattner, M.F., 2015. Is democracy in decline? Journal of Democracy, 26(1), pp.5-10.

Plattner, M.F., 2019. Illiberal democracy and the struggle on the right. Journal of Democracy, 30(1), pp.5-19.

Popper, K., 1945. Open society and its enemies. Routledge.

Powell, J.M. and Thyne, C.L., 2011. Global instances of coups from 1950 to 2010: A new dataset. Journal of Peace Research, 48(2), pp.249-259.

Przeworski, A., Alvarez, R.M., Alvarez, M.E., Cheibub, J.A., Limongi, F., Neto, F.P.L., et al., 2000. Democracy and development: Political institutions and well-being in the world, 1950-1990. Cambridge University Press.

Rohrschneider, R. and Whitefield, S., 2009. Understanding cleavages in party systems: issue position and issue salience in 13 post-communist democracies. Comparative Political Studies, 42(2), pp.280-313.

Rooduijn, M., 2014. The nucleus of populism: In search of the lowest common denominator. Government and Opposition, 49(4), pp.573-599.

Rydgren, J., 2017. Radical right-wing parties in Europe: what's populism got to do with it? Journal of Language and Politics, 16(4), pp.485-496.

Sánchez-Cuenca, I., 2003. Power, rules, and compliance. Democracy and the Rule of Law, 5, p.62.

Sartori, G., 1997. Understanding pluralism. Journal of Democracy, 8(4), pp.58-69.

Schamis, H.E., 2006. A "left turn" in Latin America? populism, socialism, and democratic institutions. Journal of Democracy, 17(4), pp.20-34.

Schedler, A., 2002. Elections without democracy: the menu of manipulation. Journal of Democracy, 13(2), pp.36-50.

Singer, M., 2018. Delegating away democracy: How good representation and policy successes can undermine democratic legitimacy. Comparative Political Studies, 51(13), pp.1754-1788.

Svolik, M., 2008. Authoritarian reversals and democratic consolidation. American Political Science Review, pp.153-168.

Svolik, M., 2015. Which democracies will last? Coups, incumbent takeovers, and the dynamic of democratic consolidation. British Journal of Political Science, 45(4), pp.715-738. 
Svolik, M., 2018. When polarization trumps civic virtue: Partisan conflict and the subversion of democracy by incumbents. Available at SSRN 3243470.

Taspinar, O., 2014. The end of the Turkish model. Survival, 56(2), pp.49-64.

Teorell, J. and Lindberg, S.I., 2015. The structure of the executive in authoritarian and democratic regimes: regime dimensions across the globe, 1900-2014. V-Dem Working Paper, 5.

Tomini, L. and Wagemann, C., 2018. Varieties of contemporary democratic breakdown and regression: A comparative analysis. European Journal of Political Research, 57(3), pp.687-716.

Varshney, A., 2019. Modi consolidates power: electoral vibrancy, mounting liberal deficits. Journal of Democracy, 30(4), pp.63-77.

Verbeek, B. and Zaslove, A., 2016. Italy: a case of mutating populism? Democratization, 23(2), pp.304-323.

Volkens, A., Krause, W., Lehmann, P., Matthiess, T., Merz, N., Regel, S., and Wessels, B., 2019. The manifesto data collection. Manifesto project (MRG/CMP/MARPOR). Version $2019 \mathrm{~b}$.

Waldner, D. and Lust, E., 2018. Unwelcome change: coming to terms with democratic backsliding. Annual Review of Political Science, 21, pp.93-113.

Weyland, K., 2013. Latin America's authoritarian drift: the threat from the populist left. Journal of Democracy, 24(3), pp.18-32.

Zakaria, F., 1997. The rise of illiberal democracy. Foreign Affairs, 76, p.22.

Ziblatt, D., 2017. Conservative political parties and the birth of modern democracy in Europe. Cambridge University Press. 


\section{Appendix}

\section{A Expert survey items}

This is the original question wording from the V-Party codebook. ${ }^{35}$ Note that in this paper, we have flipped the scales of all four indicators, so that higher values signal higher levels of antipluralism.

\section{A.1 Political opponents (v2paopresp)}

Prior to this election, have leaders of this party use severe personal attacks or tactics of demonization against their opponents?

Clarification: Severe personal attacks and demonization includes dehumanizing opponents or describing them as an existential threat or as subversive, criminal or foreign agents.

0. Always. Party leaders always used severe personal attacks or tactics of demonization against their opponents.

1. Usually. Party leaders usually used severe personal attacks or tactics of demonization against their opponents.

2. About half of the time. Party leaders sometimes used severe personal attacks or tactics of demonization against their opponents.

3. Usually not. Party leaders usually did not use severe personal attacks or tactics of demonization against their opponents.

4. Never. Party leaders never used severe personal attacks or tactics of demonization against their opponents.

\section{A.2 Democratic process (v2paplur)}

Prior to this election, to what extent was the leadership of this political party clearly committed to free and fair elections with multiple parties, freedom of speech, media, assembly and association?

Clarification: Party leaders show no commitment to such principles if they openly support an autocratic form of government without elections or freedom of speech, assembly and association (e.g.theocracy; single-party rule; revolutionary regime). Party leaders show a full commitment to key democratic principles if they unambiguously support freedom of speech, media, assembly and association and pledge to accept defeat in free and fair elections.

0. Not at all committed. The party leadership was not at all committed to free and fair, multiparty elections, freedom of speech, media, assembly and association.

35 Source: Lührmann et al., 2020 
1. Not committed. The party leadership was not committed to free and fair, multi-party elections, freedom of speech, media, assembly and association.

2. Weakly committed. The party leadership was weakly committed to free and fair, multiparty elections, freedom of speech, media, assembly and association.

3. Committed. The party leadership was committed to free and fair, multi-party elections, freedom of speech, media, assembly and association.

4. Fully committed. The party leadership was fully committed to free and fair, multi-party elections, freedom of speech, media, assembly and association.

\section{A.3 Minority rights (v2paminor)}

According to the leadership of this party, how often should the will of the majority be implemented even if doing so would violate the rights of minorities?

Clarification: This concerns the rights enshrined in the Universal Declaration of Human Rights, which apply to everyone "without distinction of any kind, such as race, colour, sex, language, religion, political or other opinion, national or social origin, property, birth or other status." The declaration protects - among others - freedom of speech, property, religion, peaceful assembly and association.

0. Always. The leadership of this party argues that the will of the majority should always determine policy even if such policy violates minority rights.

1. Usually. The leadership of this party argues that the will of the majority should usually determine policy even if such policy violates minority rights.

2. Half of the time. The leadership of this party argues that the will of the majority should about half of the time determine policy even if such policy violate minority rights.

3. Usually not. The leadership of this party argues that the will of the majority should usually not determine policy if such policy violates minority rights.

4. Never. The leadership of this party argues that the will of the majority should never determine policy if such policy violates minority rights.

\section{A.4 Rejection of political violence (v2paviol)}

To what extent does the leadership of this party explicitly discourage the use of violence against domestic political opponents?

Clarification: "Domestic political opponents" refers to all political opponents, with the exception of those who are engaged in an armed conflict with the state. They may be other political parties or other political groups and movements.

0. Encourages. Leaders of this party often encourage the use of violence against domestic political opponents.

1. Sometimes encourages. Leaders of this party sometimes encourage the use of violence against domestic political opponents and generally refrain from discouraging it. 
2. Discourages about half of the time. Leaders of this party occasionally discourage the use of violence against domestic political opponents, and do not encourage it.

3. Generally discourages. Leaders of this party often discourage the use of violence against its domestic political opponents.

4. Consistently discourages. Leaders of this party consistently reject the use of violence against its domestic political opponents.

\section{B Data validation}

\section{B.1 Additional visualizations of anti-pluralist characteristics}

Figure B.1: The anti-pluralism index and its input indicators (1970-2019) in the whole V-Party dataset.
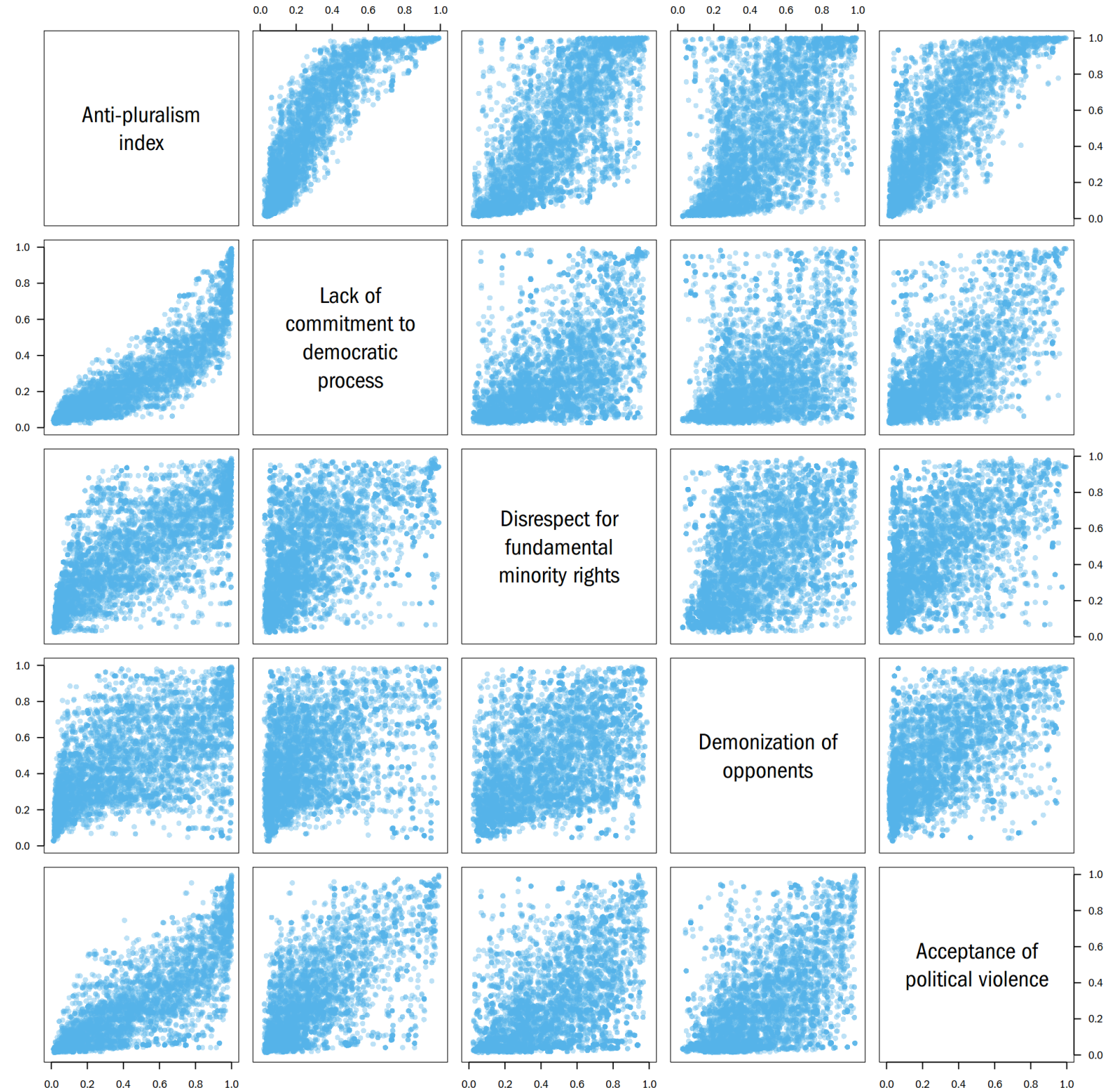
Figure B.2: The anti-pluralism index and its input indicators (1970-2018) in the analyzed subset of cases $(N=771)$. Observations autocratization episodes at $t+1$ highlighted in orange.
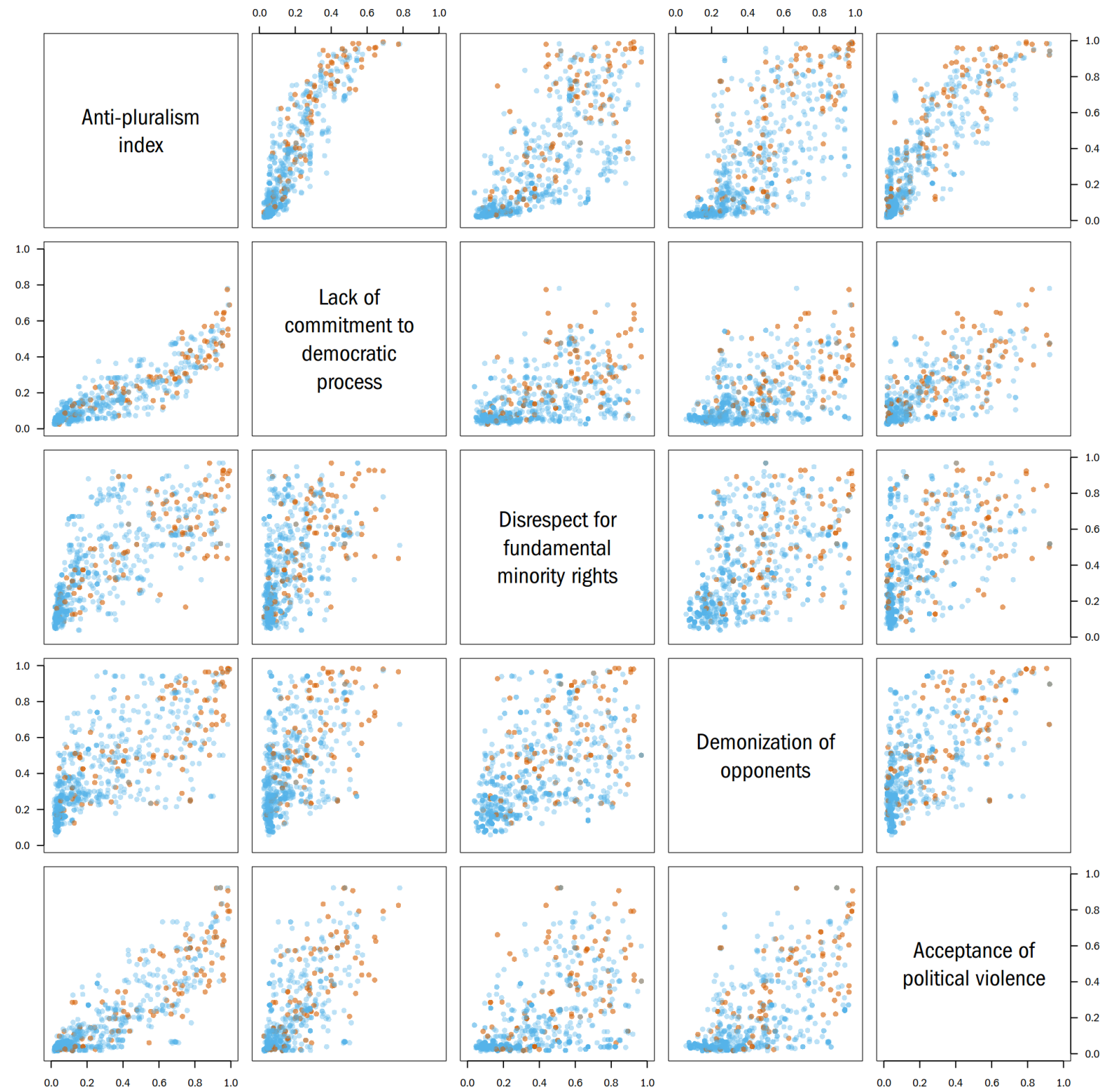

Figure B.3: The Anti-Pluralism Index with a density estimate in the analyzed sample $(N=771)$ and ten cases selected to illustrate different points on the scale.

\section{Anti-Pluralism}

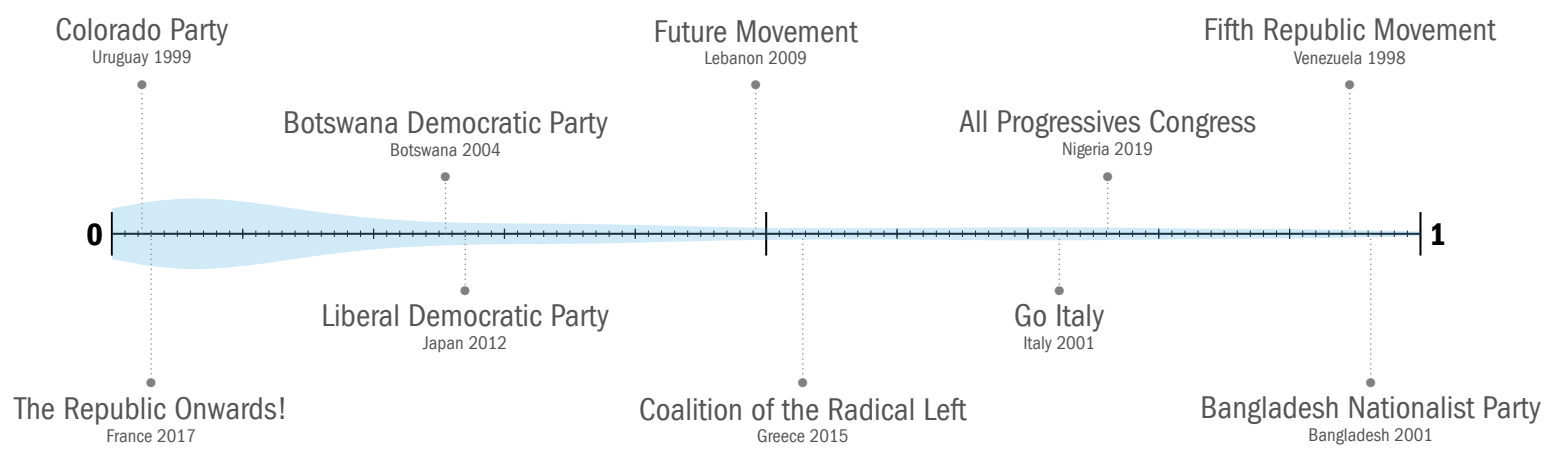




\section{B.2 Populist characteristics}

Most measures of populism focus on the anti-elitism of populists. For instance, the widely used CHES data set (Polk and Rovny, 2017) includes two indicators capturing the salience of antiestablishment/elite rhetoric and of anti-corruption rhetoric of political parties as well as an indicator of their position on direct democracy ${ }^{36}$. Norris and Inglehart $(2019$, p. 230) use the first two to capture their notion of populist political parties. ${ }^{37}$ While these aspects are important for capturing populism, this choice of indicators is problematic, as it is equally important to include a measure of a notion of "the people" as homogenous and pure. As Mudde and Kaltwasser (2013, p. 150-51) note, populists do not only promote anti-elitist views, they also argue that there is a homogenous people whose general will should be realized and whom they represent. The sovereignty of the will of the homogenous and pure people over the will of the homogenous and corrupt elite is central to populist ideology, and thus solely measures of anti-elitism are not sufficient to capture populist ideologies without including the notion of group homogeneity.

In addition, the CHES indicator on direct democracy does not help much to capture populism as the cleavage direct vs. representative democracy is not at the heart of what populism is about (Müller, 2017, p. 25).

The V-Party data set includes two indicators to capture populism: One that focuses on the anti-elitism rhetoric of populist parties (Anti-Elitism), building on Schedler (1996, p.293) and another one on the citizen centrism of populists (People-Centrism). Combined to one index (Populism), these indicators enable the measurement of a thin version of populism. ${ }^{38}$

Following the arguments of Castanho Silva et al. (2020) and Wuttke, Schimpf, and Schoen (2020), the V-Party data set includes a populism index that does not take the two input indexes as fully substitutable (v2xpa_popul). These recent contributions show that populism is better understood as a configuration of certain attributes rather then as their simple or weighted average, and is best measured as such. Accordingly, V-Party computes the populism score of a party in the following way. First, they rescale the OSP versions of the input variables onto the unit interval with dividing them by four. Next, the harmonic mean of these values is computed. Informally, the harmonic mean can be interpreted as in between taking the minimum as recommended by Castanho Silva et al. (2020) and taking a (weighted) arithmetic mean, but much closer to taking the minimum. In other words, this allows for some substitutability between the input indexes, but only to a very limited degree. This limited substitutability gives the resulting populism index some degree of robustness with regards to large downward errors in the input indexes.

Figure B.4 gives a density plot of the values on the Populism index.

$36 \quad$ The entry in the CHES codebook (2017, p. 13) reads: "position on direct vs. representative democracy. Some political parties take the position that the people' should have the final say on the most important issues, for example, by voting directly in referendums. At the opposite pole are political parties that believe that elected representatives should make the most important political decisions."

37 Norris and Inglehart (2019, p. 230) use CHES round 2014, which had not yet included the question on direct democracy.

38 Wiesehomeier (2018) shows that a unidimensional measure of populism tends to correlate with two-dimensional (anti-elite and citizen-centric) approaches to populism, but there are important exceptions. Therefore-and in order to enhance measurement reliability-V-Party has inquired into both aspects here individually. We follow Wiesehomeier (2018, p.8) approach of refraining from including the term "populism" in the expert survey as it is a loaded and ambiguous concept. 
Figure B.4: The populism scale, with a density estimate of the scores in the analyzed sample $(N=771)$ and ten selected parties illustrating selected points on the scale.

Populism

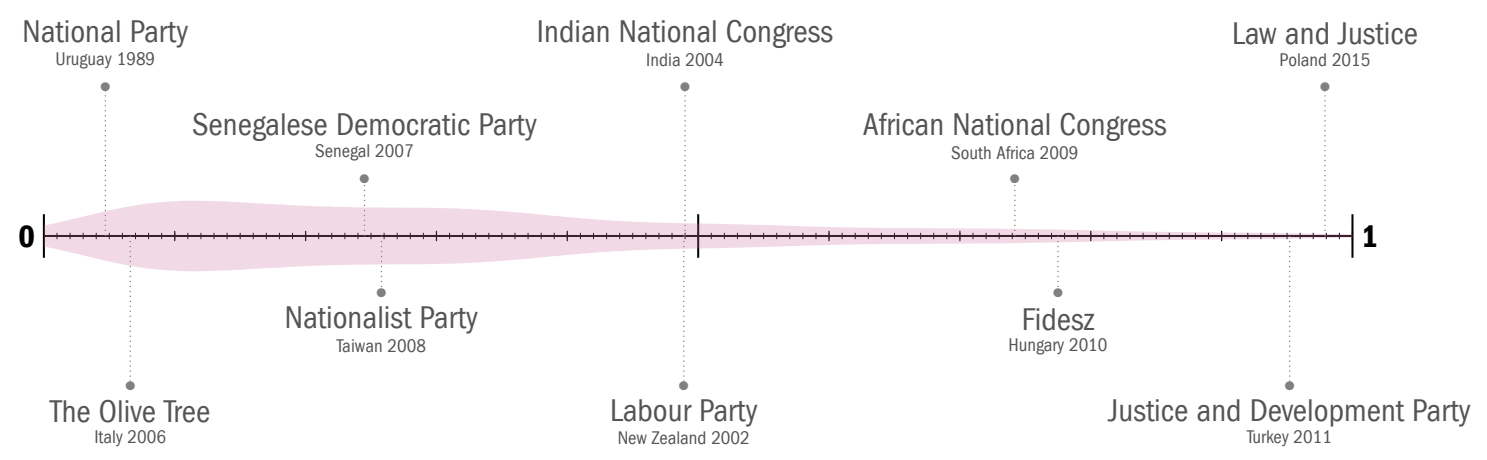

\section{B.3 Cultural dimension of the party system}

V-Party also captures the so-called second or cultural dimension in the party system. This dimension has often been called GALTAN- Green, Alternative, Libertarian vs. Traditional, Authoritarian, National. These aspects have been found to correlate highly in opinion surveys (Kitschelt and Rehm, 2014) and thus, expert surveys such as CHES conflate them into one question. ${ }^{39}$

The V-Party survey includes the following items to capture the cultural dimension:

- Immigration (v2paimmig),

- LGBT Social equality (v2palgbt),

- Cultural superiority (v2paculsup),

- religious principles (v2parelig),

- and working women (v2pawomlab). [see Lührmann et al. (2020) for question text]

For this paper, we aggregated them using first Bayesian Factor Analysis with a single latent factor and then used the standard normal CDF to rescale the factor scores onto the unit interval so that in the resulting index 0 stands for progressive and 1 for conservative. Figure B. 5 shows the distribution in the analyzed sample.

\section{B.4 The economic left-right dimension in party system}

Figure B.6 gives the distribution of the data on the economic left-right dimension (v2pargilef_osp).

$39 \quad$ CHES (Polk and Rovny, 2017) asks to place experts on a 0 to 10 scale with regards to: "position of the party in terms of their views on democratic freedoms and rights. 'Libertarian' or 'postmaterialist' parties favor expanded personal freedoms, for example, access to abortion, active euthanasia, same-sex marriage, or greater democratic participation. Traditional' or authoritarian' parties often reject these ideas; they value order, tradition, and stability, and believe that the government should be a firm moral authority on social and cultural issues"; as well as "position of the party in terms of a cultural dimension with Green/Alternative/Libertarian (GAL) at one extreme and Traditionalist/Nationalist/Authoritarian (TAN) at the other extreme." 
Figure B.5: Cultural dimension index, from least to most conservative, with a density estimate of the posterior median values in the subset of the data used in the analysis $(N=771)$. Ten selected parties highlight different points on the scale.

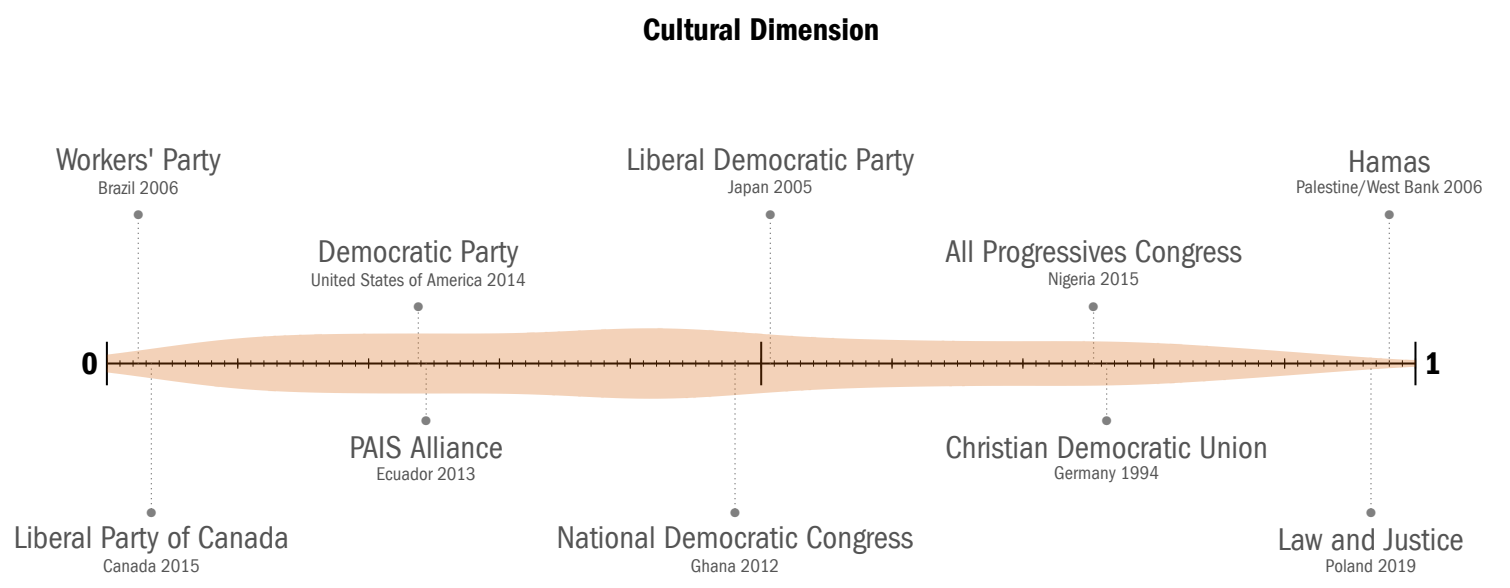

Figure B.6: Economic Left-Right index (v2pargilef_osp divided by 6), with a density estimate of the posterior median values in the subset of the data included in the analysis $(N=771)$. Ten selected parties highlight different points on the scale.

Economic Left-Right

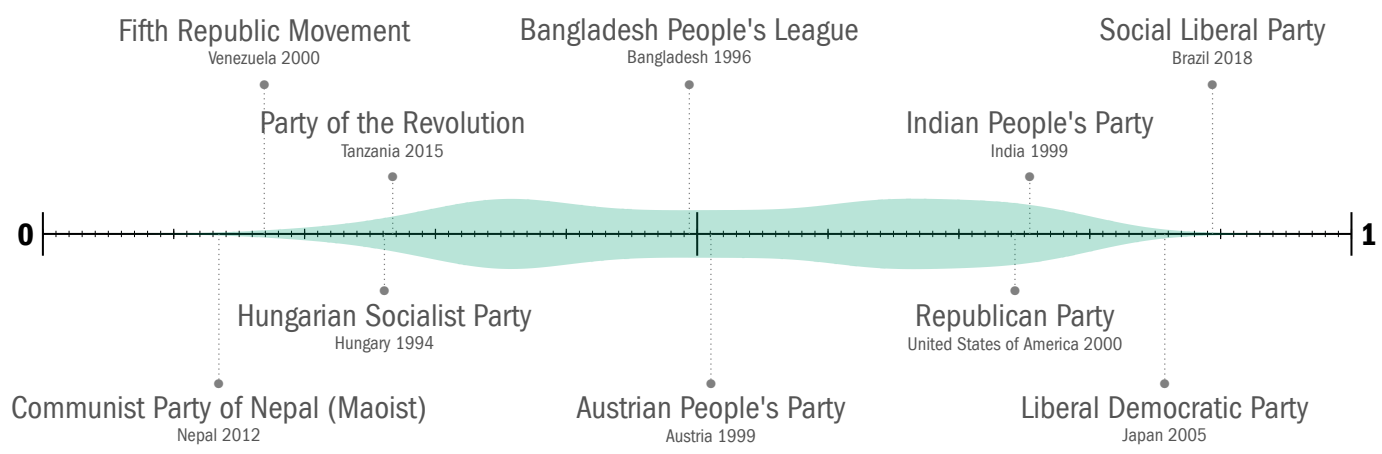

\section{B.5 Multiple dimensions in the party system}

Figure B.7 gives the joint and marginal distributions of the discussed indices of party characteristics. The wide distribution of the scatter illustrates that these measures indeed capture distinct dimensions in the party system. 
Figure B.7: Four indexes (1970-2019) in the analyzed subset of cases $(N=771)$. Observations autocratization episodes at $t+1$ highlighted in orange.

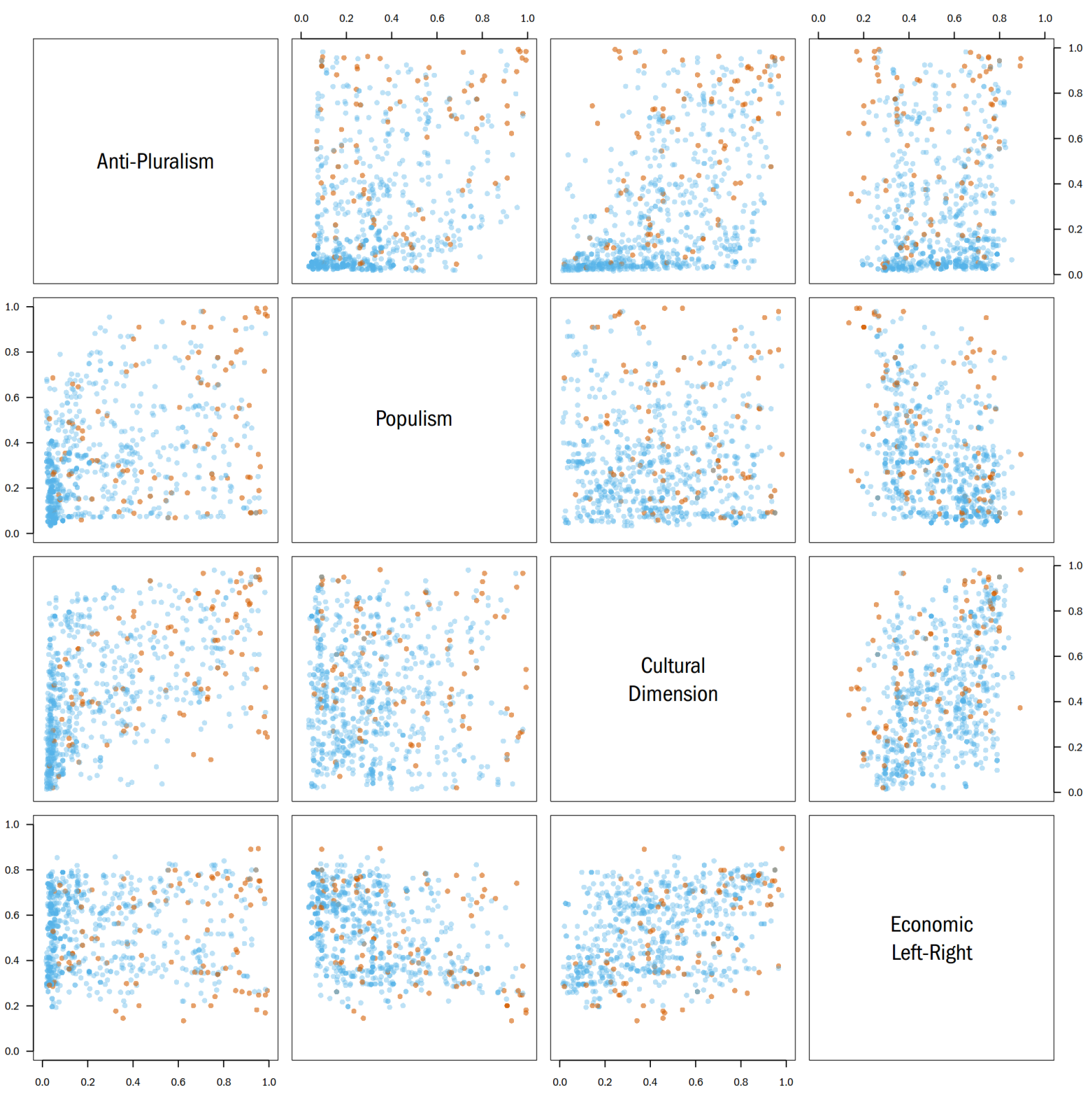




\section{B.6 The case of the United States of America 2000-19}

Figure B.8: US Democrats and Republicans 2000-18 compared on a range of indicators and indexes.
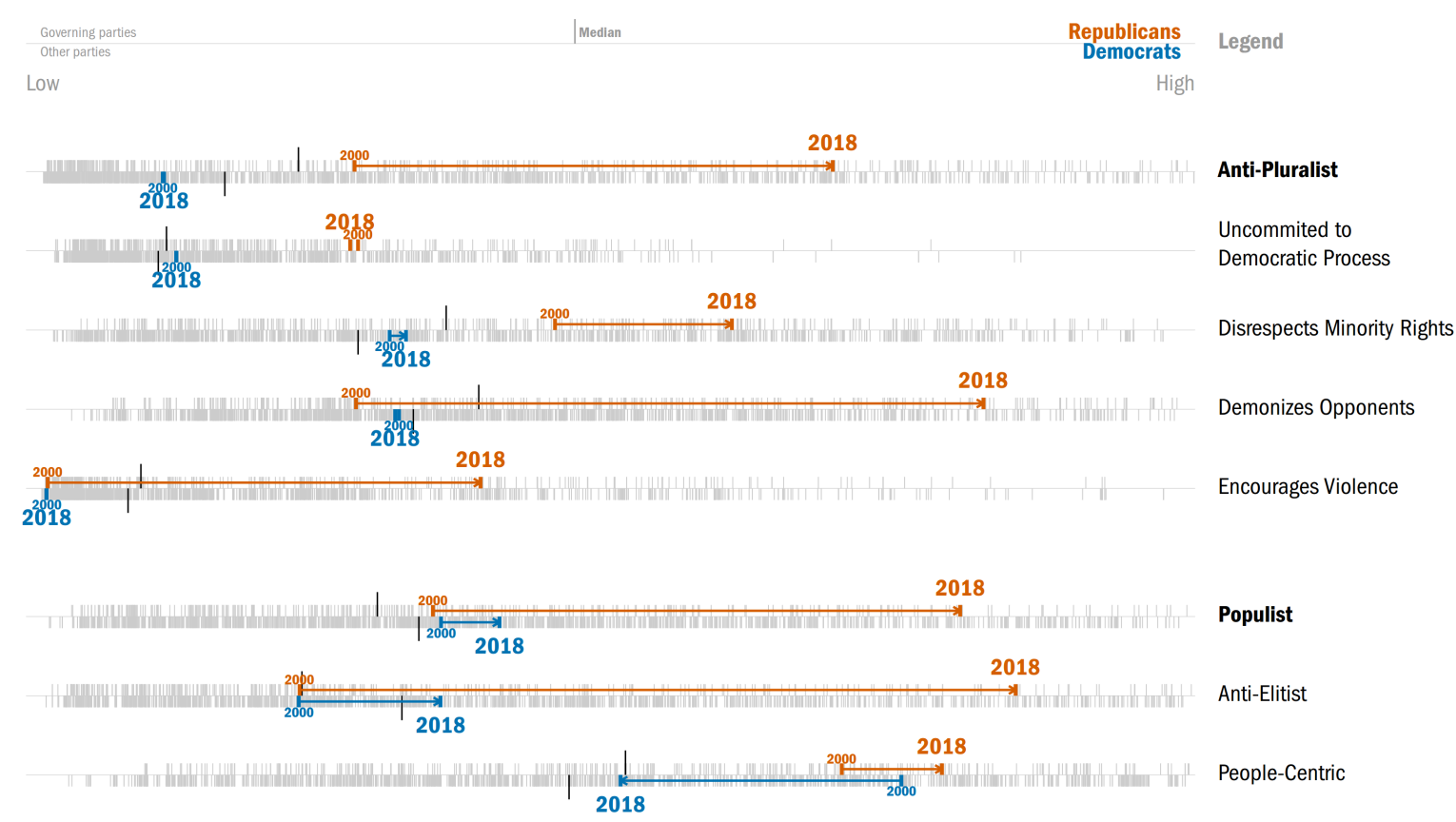

Populist

Anti-Elitist

People-Centric

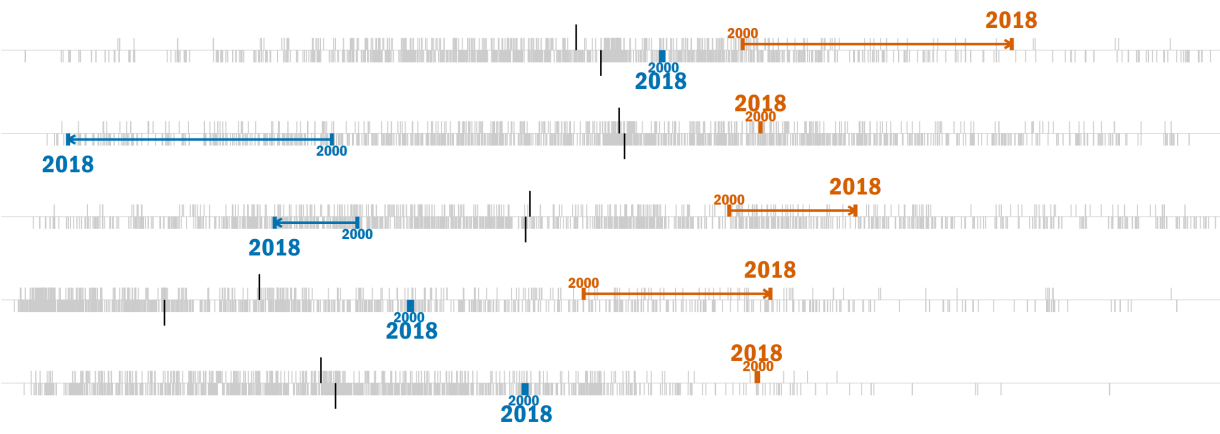

Anti-Immigration

Opposes LGBT Equality

Espouses Cultural

Superiority

Invokes Religion

No State Support for Working Women

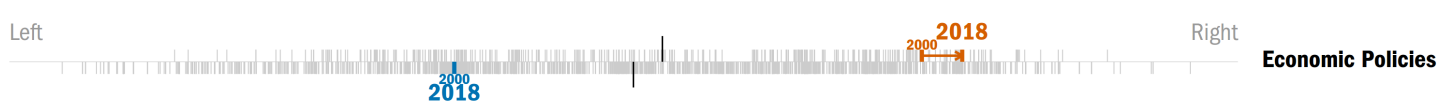

Figure B.8 illustrates that the V-Party dataset captures divergent trends over multiple dimensions in the party systems. It shows where the Republican Party (orange dots) and the Democratic Party (blue squares) placed on several indicators before the 2018 election relative to all other ruling parties in democracies (above the line) and junior governing and opposition parties in democracies (below the horizontal lines) in this millennium. The black vertical line gives the median value. The data shows that the Republican Party in 2018 was far more anti-pluralist than almost all other governing parties in democracies. Only very few governing parties in democracies in this millennium (15\%) were considered more anti-pluralist than the Republican Party in the US. Conversely, the Democratic Party was rated slightly less anti-pluralist than the typical party in democracies. The Republican party scores much higher than almost all parties in democracies on almost all of these indicators. Both parties use more populist rhetoric - anti-elitism and people-centrism - than typical parties in democracies, but the Republicans clearly more so. The five indicators 
capturing cultural issues place the Republicans consistently to the right of the center. Democrats also fare to the right of the median party in democracies in this millennium in terms of the role of religion in politics, immigration, and support of state measures to enhance the equal participation of women in the labor market. They fare to the left of the spectrum when it comes to support for LGBT equality and opposing the idea of cultural superiority of particular group or nation. V-Party's data places the Democratic Party to the left of typical parties in democracies in terms of economic issues and the Republican Party to the right. 


\section{Regressions}

Table C.1: Predictive performance of models reported in Figure C.9 and C.10. in terms of Leave-Pair-Out Area Under the Receiver Operating Characteristic Curve (LPOCV-AUC) 16 models, $4 x 2$ single party variable with and without contextual covariates.

\begin{tabular}{lllc}
\hline & & \multicolumn{2}{c}{ Contextual Covariates } \\
\cline { 3 - 4 } & & No & Yes \\
\hline \multirow{2}{*}{ Component: } & Lack of commitment to democratic process & .77 & .83 \\
& Disrespect for fundamental minority right & .72 & .81 \\
& Demonization of opponents & .73 & .82 \\
& Acceptance of political violence & .77 & .83 \\
\hline \multirow{2}{*}{ Index: } & Anti-Pluralism & .79 & .83 \\
& Populism & .66 & .82 \\
& Cultural Dimension & .61 & .81 \\
& Economic Left-Right & .62 & .83 \\
\hline
\end{tabular}


Figure C.9: Selected partial effects under Gaussian-identity GAMs with autocratization episode at $\boldsymbol{t}+\mathbf{1}$ on the lefthand-side. Dashed lines show \pm 2 SE regions. Upper ticks show cases with an autocratization episode, lower ticks cases without one. 2016 US Republicans highlighted with a larger orange tick. Figure rows from top to bottom: four components of anti-pluralism. Figure columns from left to right: (1) Four models with single party variable (shown), AIC: 358, 410, 388, 348. (2) Four models with single party variable (shown) and contextual covariates (not shown), AIC: 316, 338, 331, 325. (3) Single model with four party variables (shown), AIC 329. (4) Single model with four party variables (shown) and contextual covariates (not shown), AIC 299. $N=771$, null model AIC 455, Contextual covariates only model AIC 341.

Lack of commitment to democratic process
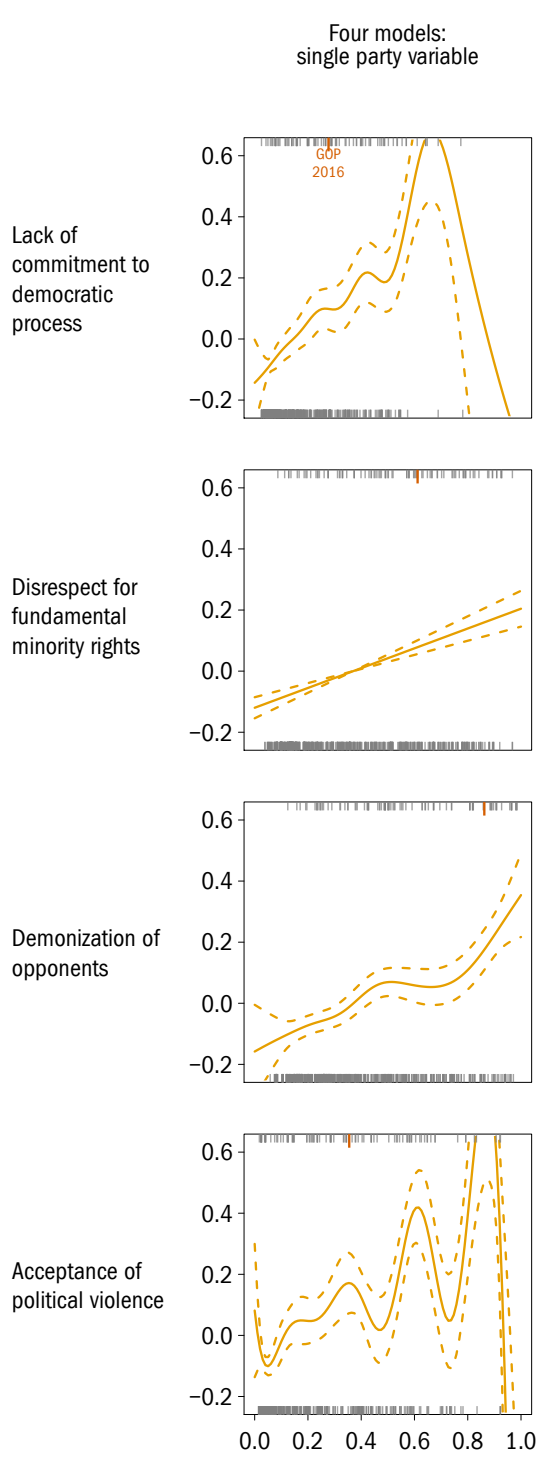

Four models:
single party variable with contextual covariate
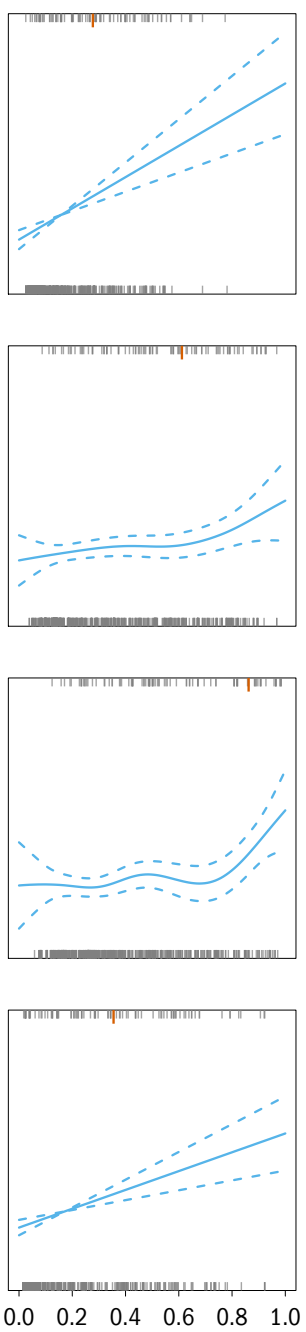

Single model: four party variables
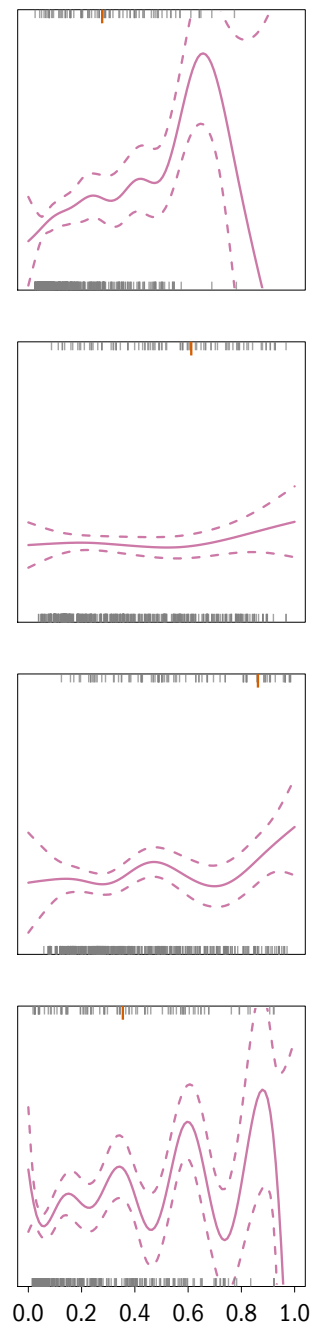

Single model: four party variables with contextual controls
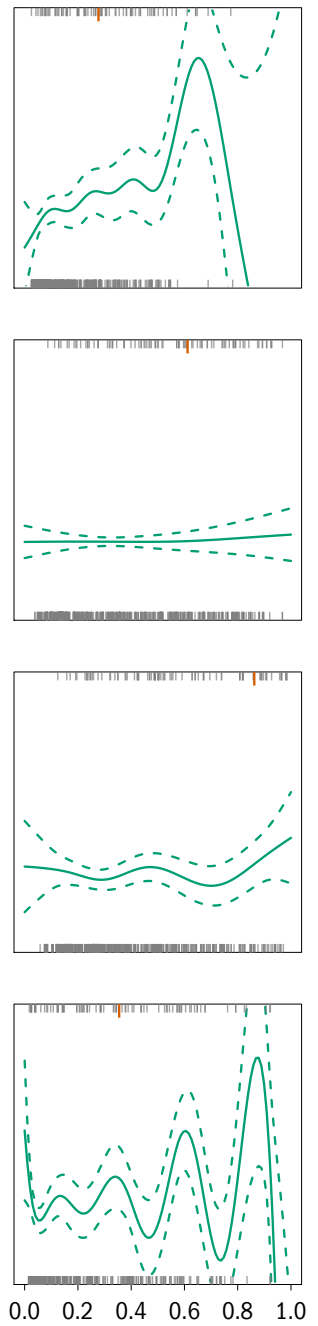
Figure C.10: Selected partial effects under Gaussian-identity GAMs with autocratization episode at $\boldsymbol{t}+\mathbf{2}$ on the lefthand-side. Dashed lines show $\pm 2 \mathrm{SE}$ regions. Upper ticks show cases with an autocratization episode, lower ticks cases without one. 2016 US Republicans highlighted with a larger orange tick. Figure rows from top to bottom: four components of anti-pluralism. Figure columns from left to right: (1) Four models with single party variable (shown), AIC: 337, 398, 429, 421. (2) Four models with single party variable (shown) and contextual covariates (not shown), AIC: 305, 312, 328, 312. (3) Single model with four party variables (shown), AIC 316. (4) Single model with four party variables (shown) and contextual covariates (not shown), AIC 276. $N=771$, null model AIC 455, Contextual covariates only model AIC 341.

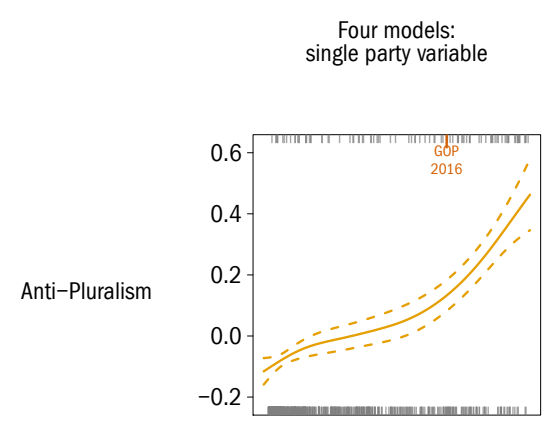

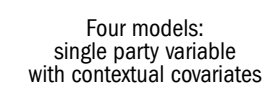
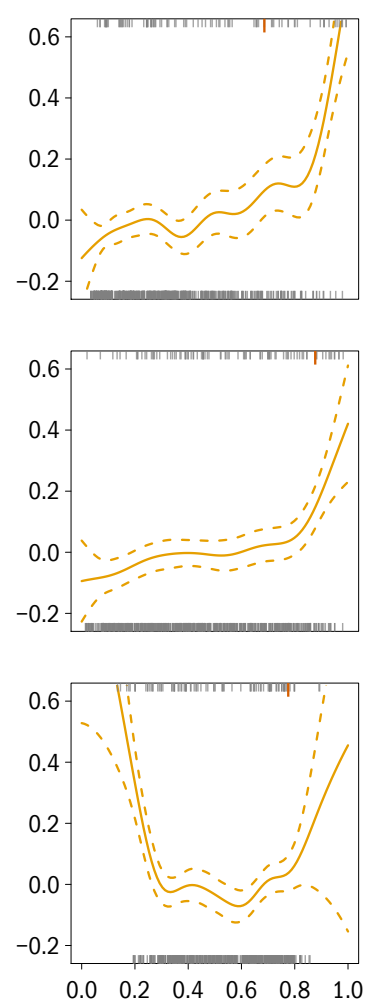
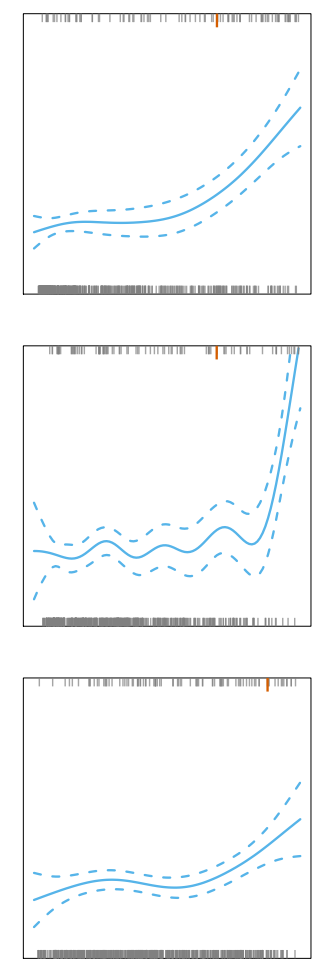
four party variable
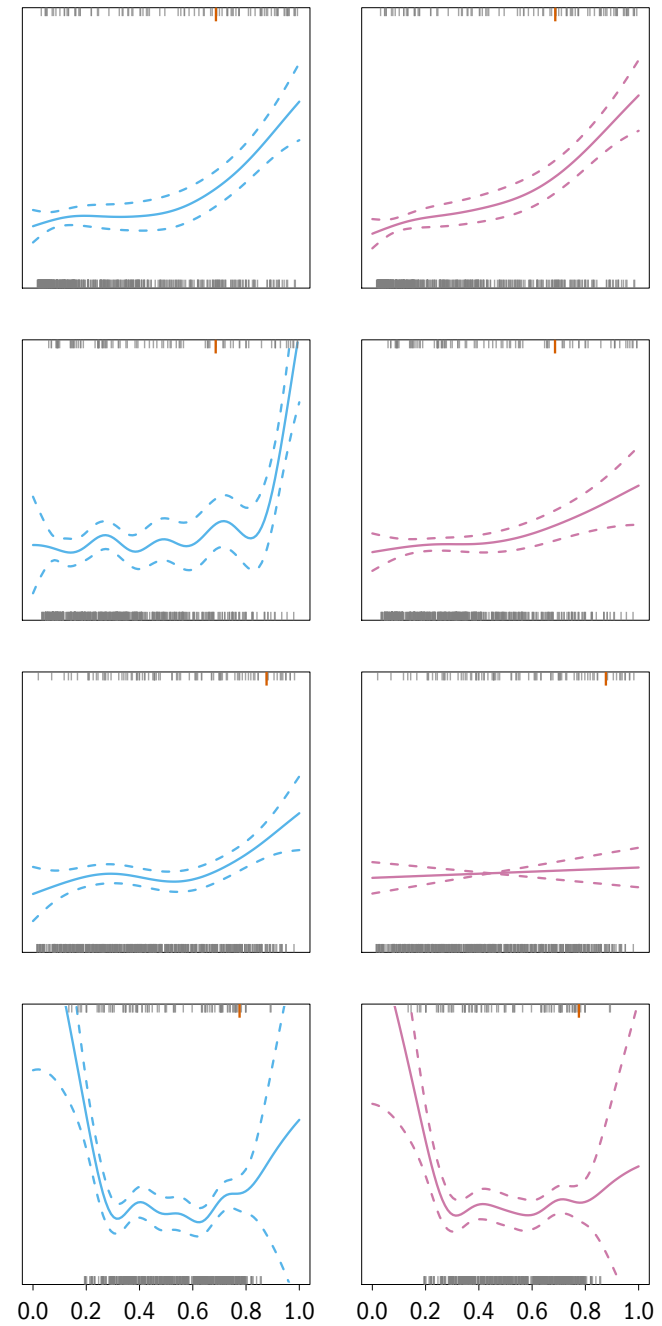
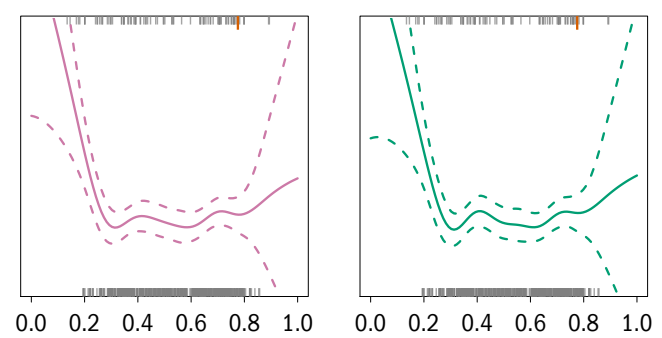
Figure C.11: Selected partial effects under Gaussian-identity GAMs with autocratization episode at $\boldsymbol{t}+\mathbf{2}$ on the lefthand-side. Dashed lines show $\pm 2 S E$ regions. Upper ticks show cases with an autocratization episode, lower ticks cases without one. 2016 US Republicans highlighted with a larger orange tick. Figure rows from top to bottom: four components of anti-pluralism. Figure columns from left to right: (1) Four models with single party variable (shown), AIC: 350, 397, 369, 339. (2) Four models with single party variable (shown) and contextual covariates (not shown), AIC: 304, 321, 312, 306. (3) Single model with four party variables (shown), AIC 331. (4) Single model with four party variables (shown) and contextual covariates (not shown), AIC 299. $N=757$.
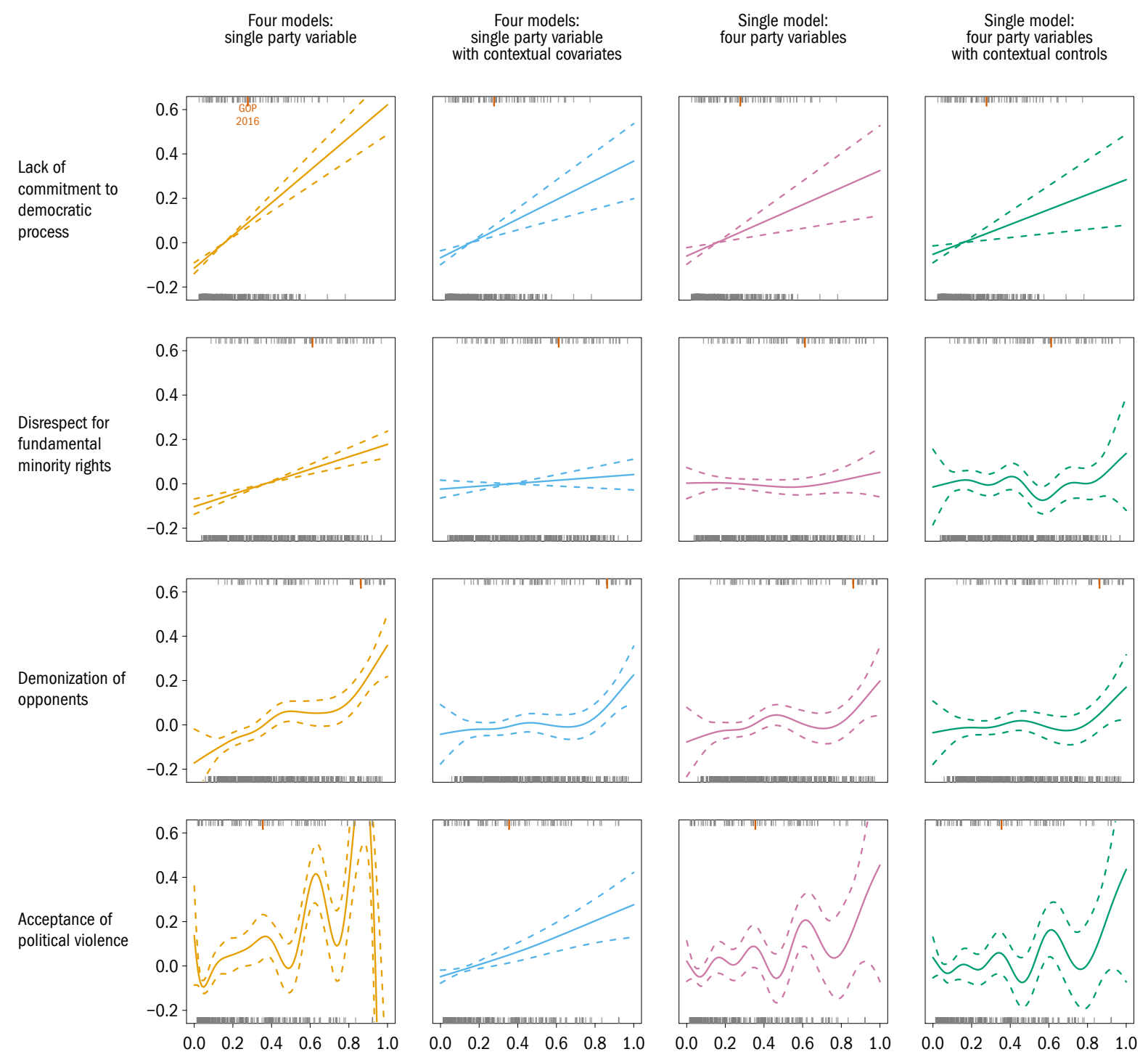
Figure C.12: Selected partial effects under Gaussian-identity GAMs with autocratization episode at $\mathbf{t}+\mathbf{2}$ on the left-hand-side. Dashed lines show $\pm 2 \mathrm{SE}$ regions. Upper ticks show cases with an autocratization episode, lower ticks cases without one. 2016 US Republicans highlighted with a larger orange tick. Figure rows from top to bottom: four components of anti-pluralism. Figure columns from left to right: (1) Four models with single party variable (shown), AIC: 329, 372, 418, 409. (2) Four models with single party variable (shown) and contextual covariates (not shown), AIC: 287, 286, 318, 306. (3) Single model with four party variables (shown), AIC 316. (4) Single model with four party variables (shown) and contextual covariates (not shown), AIC 267. $N=757$.
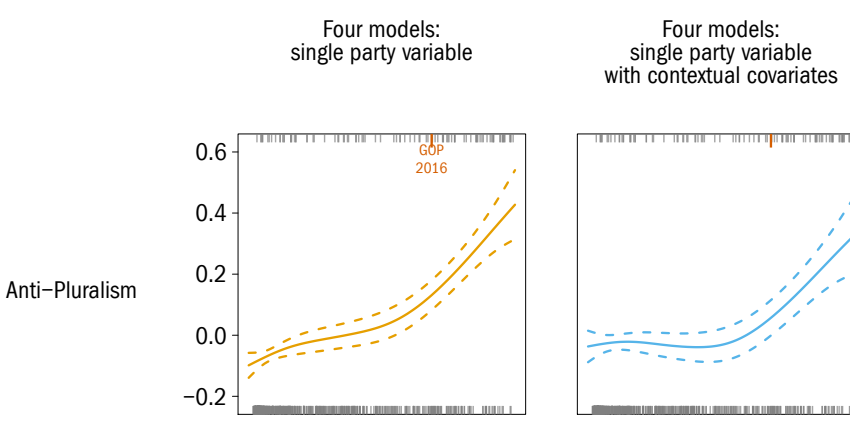

with contextual covariates
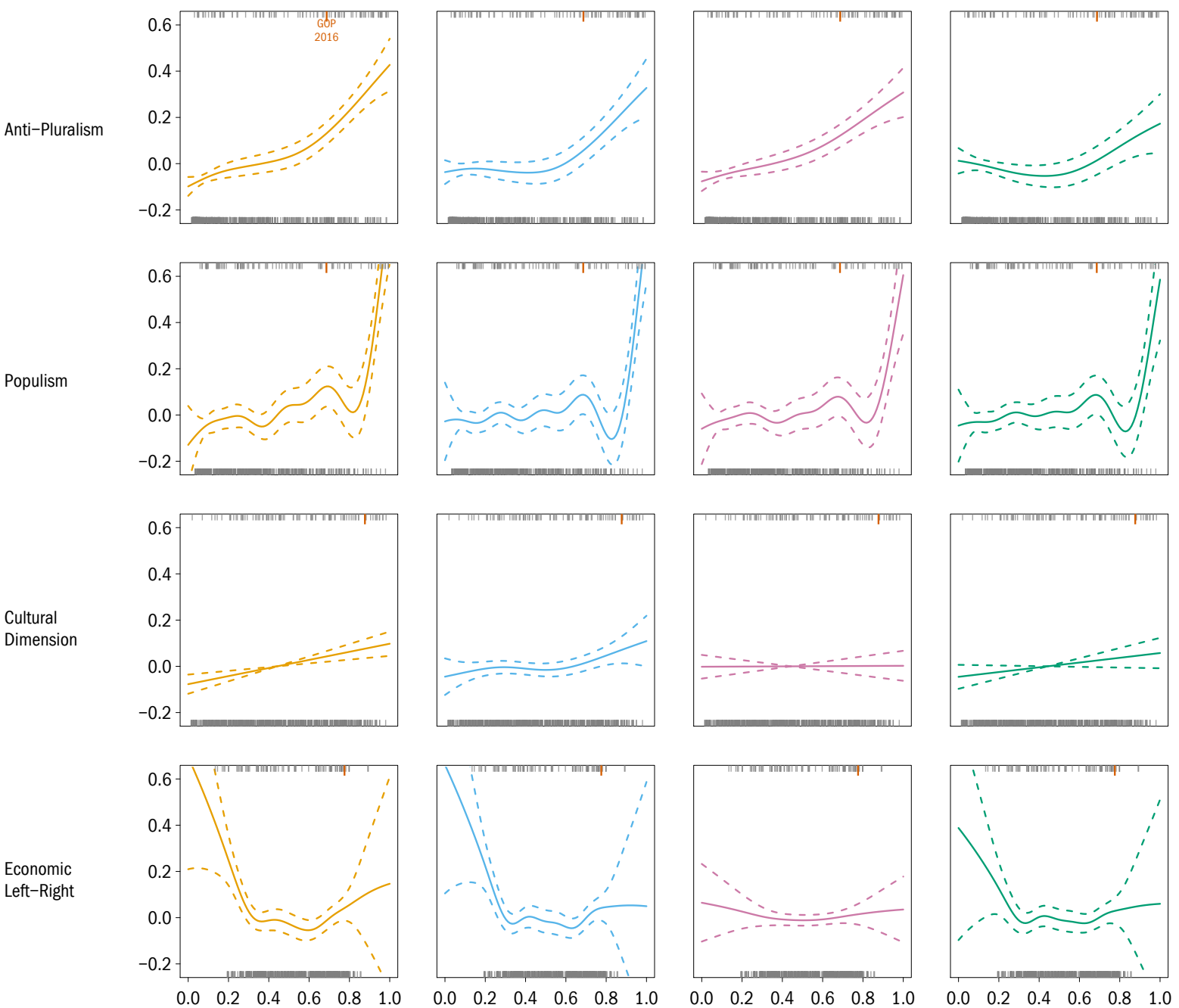
Figure C.13: Selected partial effects under Gaussian-identity GAMs with autocratization episode at $\mathbf{t}+\mathbf{3}$ on the left-hand-side. Dashed lines show \pm 2 SE regions. Upper ticks show cases with an autocratization episode, lower ticks cases without one. 2016 US Republicans highlighted with a larger orange tick. Figure rows from top to bottom: four components of anti-pluralism. Figure columns from left to right: (1) Four models with single party variable (shown), AIC: 346, 388, 363, 326. (2) Four models with single party variable (shown) and contextual covariates (not shown), AIC: 296, 314, 298, 280. (3) Single model with four party variables (shown), AIC 317. (4) Single model with four party variables (shown) and contextual covariates (not shown), AIC 272. $N=739$.

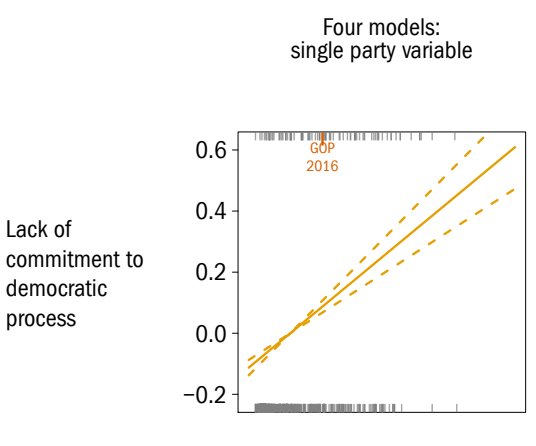

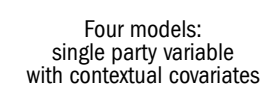
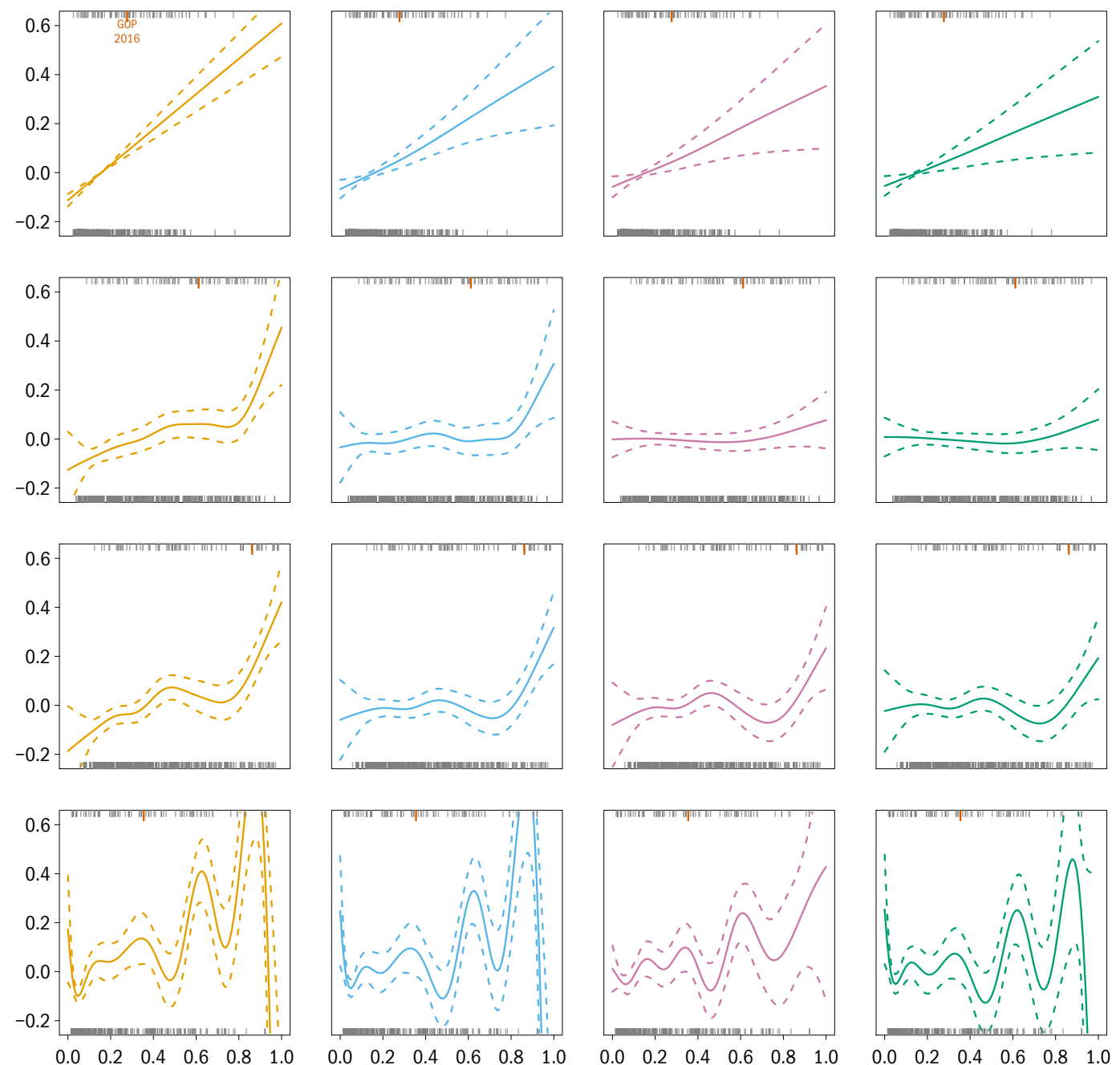
Figure C.14: Selected partial effects under Gaussian-identity GAMs with autocratization episode at $\boldsymbol{t}+\mathbf{3}$ on the lefthand-side. Dashed lines show $\pm 2 \mathrm{SE}$ regions. Upper ticks show cases with an autocratization episode, lower ticks cases without one. 2016 US Republicans highlighted with a larger orange tick. Figure rows from top to bottom: four components of anti-pluralism. Figure columns from left to right: (1) Four models with single party variable (shown), AIC: 325 , 361, 409, 398. (2) Four models with single party variable (shown) and contextual covariates (not shown), AIC: 274, 278, 310, 294. (3) Single model with four party variables (shown), AIC 307. (4) Single model with four party variables (shown) and contextual covariates (not shown), AIC 248. $N=739$.
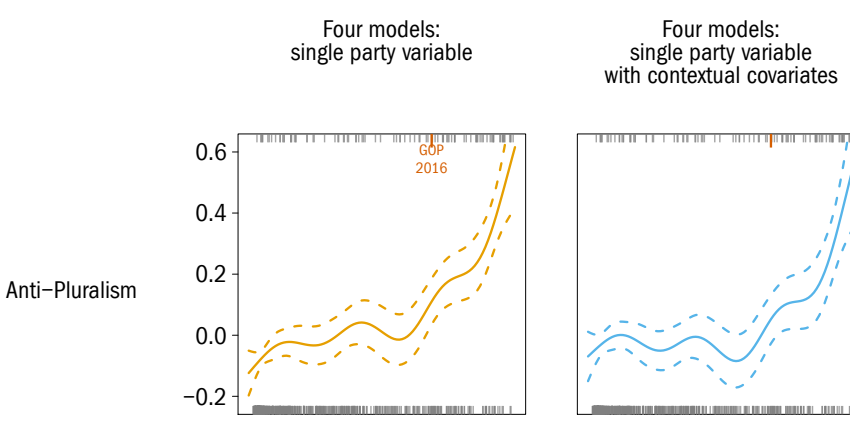
with contextual covariates
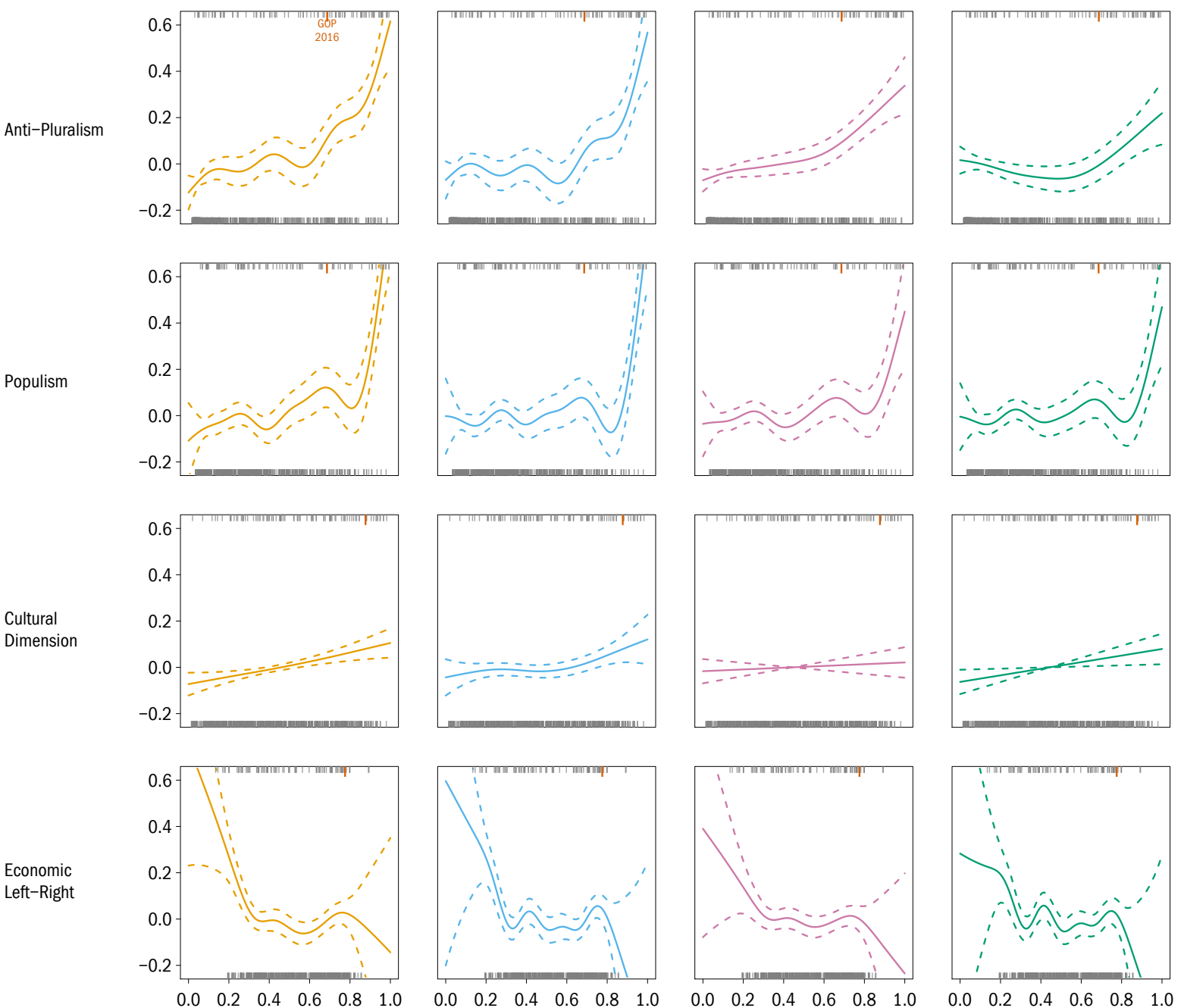
Table C.2: Re-analysis of the data with Binomial-probit GLMs.

\begin{tabular}{|c|c|c|c|c|c|c|c|c|c|c|}
\hline & \multicolumn{10}{|c|}{ Dependent variable: } \\
\hline & \multicolumn{10}{|c|}{ Autocratization episode at $t+1$} \\
\hline & (1) & (2) & (3) & (4) & (5) & (6) & (7) & (8) & (9) & (10) \\
\hline $\begin{array}{l}\text { Lack of commitment } \\
\text { to democratic process }\end{array}$ & $\begin{array}{c}3.36 \\
(0.39)\end{array}$ & & & & $\begin{array}{c}1.99 \\
(0.54)\end{array}$ & & & & $\begin{array}{c}1.73 \\
(0.58)\end{array}$ & $\begin{array}{r}1.46 \\
(0.64)\end{array}$ \\
\hline $\begin{array}{l}\text { Disrespect for fundamental } \\
\text { minority rights }\end{array}$ & & $\begin{array}{c}1.59 \\
(0.24)\end{array}$ & & & & $\begin{array}{c}0.57 \\
(0.32)\end{array}$ & & & $\begin{array}{c}0.38 \\
(0.32)\end{array}$ & $\begin{array}{r}0.06 \\
(0.36)\end{array}$ \\
\hline Demonization of opponents & & & $\begin{array}{c}1.82 \\
(0.24)\end{array}$ & & & & $\begin{array}{c}0.87 \\
(0.32)\end{array}$ & & $\begin{array}{c}0.62 \\
(0.33)\end{array}$ & $\begin{array}{r}0.46 \\
(0.37)\end{array}$ \\
\hline Acceptance of political violence & & & & $\begin{array}{l}2.26 \\
(0.27)\end{array}$ & & & & $\begin{array}{c}1.16 \\
(0.38)\end{array}$ & $\begin{array}{c}0.76 \\
(0.42)\end{array}$ & $\begin{array}{r}0.34 \\
(0.49)\end{array}$ \\
\hline Liberal Component Index $(t-1)$ & & & & & $\begin{array}{l}-1.56 \\
(0.74)\end{array}$ & $\begin{array}{l}-2.59 \\
(0.66)\end{array}$ & $\begin{array}{l}-2.16 \\
(0.70)\end{array}$ & $\begin{array}{l}-2.01 \\
(0.71)\end{array}$ & & $\begin{array}{l}-1.23 \\
(0.76)\end{array}$ \\
\hline $\ln \operatorname{pcGDP}(t-1)$ & & & & & $\begin{array}{l}-0.21 \\
(0.11)\end{array}$ & $\begin{array}{l}-0.25 \\
(0.10)\end{array}$ & $\begin{array}{l}-0.29 \\
(0.10)\end{array}$ & $\begin{array}{c}-0.20 \\
(0.11)\end{array}$ & & $\begin{array}{l}-0.21 \\
(0.11)\end{array}$ \\
\hline GDP growth $(t-1)$ & & & & & $\begin{array}{l}-1.41 \\
(1.21)\end{array}$ & $\begin{array}{l}-1.56 \\
(1.18)\end{array}$ & $\begin{array}{c}-1.63 \\
(1.18)\end{array}$ & $\begin{array}{l}-1.76 \\
(1.19)\end{array}$ & & $\begin{array}{l}-1.54 \\
(1.20)\end{array}$ \\
\hline Equal distribution of resources $(t-1)$ & & & & & $\begin{array}{c}0.31 \\
(0.48)\end{array}$ & $\begin{array}{c}0.55 \\
(0.48)\end{array}$ & $\begin{array}{c}0.51 \\
(0.48)\end{array}$ & $\begin{array}{c}0.54 \\
(0.47)\end{array}$ & & $\begin{array}{c}0.30 \\
(0.48)\end{array}$ \\
\hline Autocratization episodes share $(t-1)$ & & & & & $\begin{array}{l}-1.64 \\
(4.53)\end{array}$ & $\begin{array}{l}-0.94 \\
(4.45)\end{array}$ & $\begin{array}{l}-1.13 \\
(4.52)\end{array}$ & $\begin{array}{l}-0.75 \\
(4.50)\end{array}$ & & $\begin{array}{l}-1.28 \\
(4.57)\end{array}$ \\
\hline Democratization episodes share $(t-1)$ & & & & & $\begin{array}{l}-4.09 \\
(2.31)\end{array}$ & $\begin{array}{l}-4.08 \\
(2.26)\end{array}$ & $\begin{array}{l}-3.98 \\
(2.27)\end{array}$ & $\begin{array}{l}-4.08 \\
(2.30)\end{array}$ & & $\begin{array}{l}-3.79 \\
(2.31)\end{array}$ \\
\hline Exclusive regional EDI $(t-1)$ & & & & & $\begin{array}{l}-0.48 \\
(0.46)\end{array}$ & $\begin{array}{l}-0.48 \\
(0.46)\end{array}$ & $\begin{array}{l}-0.47 \\
(0.46)\end{array}$ & $\begin{array}{l}-0.63 \\
(0.46)\end{array}$ & & $\begin{array}{l}-0.45 \\
(0.48)\end{array}$ \\
\hline Presidentialism $(t-1)$ & & & & & $\begin{array}{c}-0.04 \\
(0.17)\end{array}$ & $\begin{array}{l}-0.04 \\
(0.17)\end{array}$ & $\begin{array}{l}-0.05 \\
(0.17)\end{array}$ & $\begin{array}{c}0.01 \\
(0.17)\end{array}$ & & $\begin{array}{l}-0.05 \\
(0.18)\end{array}$ \\
\hline Year & & & & & $\begin{array}{c}-1,226.93 \\
(469.43)\end{array}$ & $\begin{array}{l}-1,171.87 \\
(464.08)\end{array}$ & $\begin{array}{c}-1,201.47 \\
(469.08)\end{array}$ & $\begin{array}{c}-1,215.01 \\
(473.64)\end{array}$ & & $\begin{array}{l}-1,291.76 \\
(478.06)\end{array}$ \\
\hline Year $^{2}$ & & & & & $\begin{array}{c}0.61 \\
(0.24)\end{array}$ & $\begin{array}{l}0.59 \\
(0.23)\end{array}$ & $\begin{array}{l}0.60 \\
(0.23)\end{array}$ & $\begin{array}{c}0.61 \\
(0.24)\end{array}$ & & $\begin{array}{c}0.65 \\
(0.24)\end{array}$ \\
\hline Year $^{3}$ & & & & & $\begin{array}{c}-0.0001 \\
(<0.0001)\end{array}$ & $\begin{array}{c}-0.0001 \\
(<0.0001)\end{array}$ & $\begin{array}{c}-0.0001 \\
(<0.0001)\end{array}$ & $\begin{array}{c}-0.0001 \\
(<0.0001)\end{array}$ & & $\begin{array}{c}-0.0001 \\
(<0.0001)\end{array}$ \\
\hline Constant & $\begin{array}{l}-1.84 \\
(0.10)\end{array}$ & $\begin{array}{l}-1.86 \\
(0.13)\end{array}$ & $\begin{array}{l}-2.00 \\
(0.13)\end{array}$ & $\begin{array}{l}-1.69 \\
(0.09)\end{array}$ & $\begin{array}{l}816,796.00 \\
(312,527.80)\end{array}$ & $\begin{array}{l}780,118.70 \\
(308,984.90)\end{array}$ & $\begin{array}{l}799,786.70 \\
(312,315.70)\end{array}$ & $\begin{array}{l}808,655.80 \\
(315,345.00)\end{array}$ & $\begin{array}{l}-2.13 \\
(0.16)\end{array}$ & $\begin{array}{r}859,824.50 \\
(318,272.40)\end{array}$ \\
\hline Observations & 771 & 771 & 771 & 771 & 771 & 771 & 771 & 771 & 771 & 771 \\
\hline Log Likelihood & -243.22 & -259.85 & -253.04 & -245.38 & -207.32 & -212.46 & -210.35 & -209.11 & -235.60 & -205.57 \\
\hline AIC & 490.44 & 523.70 & 510.07 & 494.76 & 440.63 & 450.92 & 446.69 & 444.22 & 481.20 & 443.13 \\
\hline
\end{tabular}


Table C.3: Re-analysis of the data with Binomial-probit GLMs.

\begin{tabular}{|c|c|c|c|c|c|c|c|c|c|c|}
\hline & \multicolumn{10}{|c|}{ Dependent variable: } \\
\hline & \multicolumn{10}{|c|}{ Autocratization episode at $t+1$} \\
\hline & (1) & (2) & (3) & (4) & (5) & (6) & (7) & (8) & (9) & (10) \\
\hline Anti-pluralism & $\begin{array}{c}1.90 \\
(0.21)\end{array}$ & & & & $\begin{array}{c}1.17 \\
(0.31)\end{array}$ & & & & $\begin{array}{c}1.67 \\
(0.26)\end{array}$ & $\begin{array}{r}0.67 \\
(0.37)\end{array}$ \\
\hline Populism & & $\begin{array}{l}1.36 \\
(0.25)\end{array}$ & & & & $\begin{array}{c}0.84 \\
(0.28)\end{array}$ & & & $\begin{array}{c}0.67 \\
(0.30)\end{array}$ & $\begin{array}{c}0.72 \\
(0.33)\end{array}$ \\
\hline Cultural dimension & & & $\begin{array}{c}1.11 \\
(0.24)\end{array}$ & & & & $\begin{array}{c}0.82 \\
(0.30)\end{array}$ & & $\begin{array}{c}0.19 \\
(0.35)\end{array}$ & $\begin{array}{r}0.63 \\
(0.39)\end{array}$ \\
\hline Economic left-right & & & & $\begin{array}{l}-0.33 \\
(0.34)\end{array}$ & & & & $\begin{array}{l}-0.14 \\
(0.40)\end{array}$ & $\begin{array}{l}-0.20 \\
(0.45)\end{array}$ & $\begin{array}{l}-0.09 \\
(0.53)\end{array}$ \\
\hline Liberal Component Index $(t-1)$ & & & & & $\begin{array}{l}-1.52 \\
(0.74)\end{array}$ & $\begin{array}{l}-2.87 \\
(0.65)\end{array}$ & $\begin{array}{l}-2.56 \\
(0.65)\end{array}$ & $\begin{array}{l}-2.93 \\
(0.64)\end{array}$ & & $\begin{array}{l}-1.82 \\
(0.75)\end{array}$ \\
\hline $\ln \operatorname{GDPpc}(t-1)$ & & & & & $\begin{array}{l}-0.19 \\
(0.11)\end{array}$ & $\begin{array}{l}-0.30 \\
(0.10)\end{array}$ & $\begin{array}{l}-0.29 \\
(0.10)\end{array}$ & $\begin{array}{l}-0.27 \\
(0.11)\end{array}$ & & $\begin{array}{l}-0.24 \\
(0.12)\end{array}$ \\
\hline GDP growth $(t-1)$ & & & & & $\begin{array}{l}-1.65 \\
(1.19)\end{array}$ & $\begin{array}{l}-1.69 \\
(1.17)\end{array}$ & $\begin{array}{c}-1.64 \\
(1.18)\end{array}$ & $\begin{array}{l}-1.56 \\
(1.19)\end{array}$ & & $\begin{array}{l}-1.85 \\
(1.18)\end{array}$ \\
\hline Equal distribution of resources $(t-1)$ & & & & & $\begin{array}{c}0.38 \\
(0.48)\end{array}$ & $\begin{array}{c}0.70 \\
(0.48)\end{array}$ & $\begin{array}{c}0.64 \\
(0.48)\end{array}$ & $\begin{array}{c}0.62 \\
(0.48)\end{array}$ & & $\begin{array}{c}0.54 \\
(0.49)\end{array}$ \\
\hline Autocratization episodes share $(t-1)$ & & & & & $\begin{array}{l}-0.77 \\
(4.52)\end{array}$ & $\begin{array}{l}-0.81 \\
(4.50)\end{array}$ & $\begin{array}{l}-0.97 \\
(4.49)\end{array}$ & $\begin{array}{l}-1.33 \\
(4.45)\end{array}$ & & $\begin{array}{l}-0.38 \\
(4.56)\end{array}$ \\
\hline Democratization episodes share $(t-1)$ & & & & & $\begin{array}{l}-3.82 \\
(2.29)\end{array}$ & $\begin{array}{l}-4.23 \\
(2.25)\end{array}$ & $\begin{array}{l}-4.41 \\
(2.29)\end{array}$ & $\begin{array}{l}-4.41 \\
(2.27)\end{array}$ & & $\begin{array}{l}-3.96 \\
(2.28)\end{array}$ \\
\hline Exclusive regional EDI $(t-1)$ & & & & & $\begin{array}{l}-0.47 \\
(0.46)\end{array}$ & $\begin{array}{l}-0.36 \\
(0.46)\end{array}$ & $\begin{array}{l}-0.44 \\
(0.45)\end{array}$ & $\begin{array}{l}-0.61 \\
(0.45)\end{array}$ & & $\begin{array}{l}-0.22 \\
(0.48)\end{array}$ \\
\hline Presidentialism $(t-1)$ & & & & & $\begin{array}{l}-0.05 \\
(0.17)\end{array}$ & $\begin{array}{l}-0.06 \\
(0.17)\end{array}$ & $\begin{array}{c}-0.005 \\
(0.17)\end{array}$ & $\begin{array}{l}-0.01 \\
(0.17)\end{array}$ & & $\begin{array}{l}-0.07 \\
(0.17)\end{array}$ \\
\hline Year & & & & & $\begin{array}{c}-1,285.19 \\
(476.96)\end{array}$ & $\begin{array}{c}-1,055.57 \\
(461.06)\end{array}$ & $\begin{array}{c}-1,249.20 \\
(466.31)\end{array}$ & $\begin{array}{c}-1,091.19 \\
(462.26)\end{array}$ & & $\begin{array}{l}-1,254.73 \\
(477.57)\end{array}$ \\
\hline Year $^{2}$ & & & & & $\begin{array}{c}0.64 \\
(0.24)\end{array}$ & $\begin{array}{c}0.53 \\
(0.23)\end{array}$ & $\begin{array}{c}0.63 \\
(0.23)\end{array}$ & $\begin{array}{c}0.55 \\
(0.23)\end{array}$ & & $\begin{array}{c}0.63 \\
(0.24)\end{array}$ \\
\hline Year $^{3}$ & & & & & $\begin{array}{c}-0.0001 \\
(<0.0001)\end{array}$ & $\begin{array}{c}-0.0001 \\
(<0.0001)\end{array}$ & $\begin{array}{c}-0.0001 \\
(<0.0001)\end{array}$ & $\begin{array}{c}-0.0001 \\
(<0.0001)\end{array}$ & & $\begin{array}{r}-0.0001 \\
(<0.0001)\end{array}$ \\
\hline Constant & $\begin{array}{c}-1.87 \\
(0.11)\end{array}$ & $\begin{array}{r}-1.67 \\
(0.11)\end{array}$ & $\begin{array}{l}-1.71 \\
(0.14)\end{array}$ & $\begin{array}{l}-1.01 \\
(0.19)\end{array}$ & $\begin{array}{l}855,319.00 \\
(317,543.40)\end{array}$ & $\begin{array}{l}702,703.00 \\
(306,974.00)\end{array}$ & $\begin{array}{l}831,566.80 \\
(310,457.90)\end{array}$ & $\begin{array}{l}726,514.20 \\
(307,783.40)\end{array}$ & $\begin{array}{l}-2.02 \\
(0.28)\end{array}$ & $\begin{array}{r}835,004.90 \\
(317,947.30)\end{array}$ \\
\hline Observations & 771 & 771 & 771 & 771 & 771 & 771 & 771 & 771 & 771 & 771 \\
\hline Log Likelihood & -236.92 & -265.94 & -271.01 & -281.38 & -206.69 & -209.41 & -210.18 & -214.02 & -233.42 & -202.82 \\
\hline AIC & 477.84 & 535.89 & 546.02 & 566.75 & 439.38 & 444.81 & 446.36 & 454.04 & 476.83 & 437.64 \\
\hline
\end{tabular}


Table C.4: OLS regressions. Left-hand-side: Revised Polity score (Marshall, Gurr, and Jaggers, 2016) (e_polity2 in (Coppedge et al., 2020)) at last pre-election year ( $t$ - 1) and first post-election year $(t+1)$.

\begin{tabular}{|c|c|c|c|c|c|c|c|c|c|c|}
\hline & \multicolumn{10}{|c|}{ Dependent variable: } \\
\hline & \multicolumn{10}{|c|}{ Change in e_polity2 from $t-1$ to $t+1$} \\
\hline & (1) & (2) & (3) & (4) & $(5)$ & (6) & (7) & (8) & (9) & (10) \\
\hline $\begin{array}{l}\text { Lack of commitment } \\
\text { to democratic process }\end{array}$ & $\begin{array}{l}-0.62 \\
(0.35)\end{array}$ & & & & $\begin{array}{l}-1.09 \\
(0.45)\end{array}$ & & & & $\begin{array}{l}-0.72 \\
(0.53)\end{array}$ & $\begin{array}{l}-0.82 \\
(0.54)\end{array}$ \\
\hline $\begin{array}{l}\text { Disrespect for fundamental } \\
\text { minority rights }\end{array}$ & & $\begin{array}{l}0.02 \\
(0.19)\end{array}$ & & & & $\begin{array}{c}0.01 \\
(0.24)\end{array}$ & & & $\begin{array}{c}0.25 \\
(0.24)\end{array}$ & $\begin{array}{c}0.22 \\
(0.26)\end{array}$ \\
\hline Demonization of opponents & & & $\begin{array}{l}0.005 \\
(0.21)\end{array}$ & & & & $\begin{array}{l}-0.02 \\
(0.26)\end{array}$ & & $\begin{array}{l}0.40 \\
(0.29)\end{array}$ & $\begin{array}{c}0.38 \\
(0.30)\end{array}$ \\
\hline Acceptance of political violence & & & & $\begin{array}{l}-0.44 \\
(0.25)\end{array}$ & & & & $\begin{array}{l}-0.95 \\
(0.35)\end{array}$ & $\begin{array}{l}-0.54 \\
(0.39)\end{array}$ & $\begin{array}{l}-0.93 \\
(0.43)\end{array}$ \\
\hline Liberal Component Index $(t-1)$ & & & & & $\begin{array}{c}0.10 \\
(0.60)\end{array}$ & $\begin{array}{c}0.61 \\
(0.58)\end{array}$ & $\begin{array}{c}0.59 \\
(0.60)\end{array}$ & $\begin{array}{c}0.13 \\
(0.59)\end{array}$ & & $\begin{array}{c}0.18 \\
(0.62)\end{array}$ \\
\hline $\ln \operatorname{pcGDP}(t-1)$ & & & & & $\begin{array}{l}-0.13 \\
(0.08)\end{array}$ & $\begin{array}{l}-0.10 \\
(0.08)\end{array}$ & $\begin{array}{l}-0.10 \\
(0.08)\end{array}$ & $\begin{array}{l}-0.16 \\
(0.09)\end{array}$ & & $\begin{array}{l}-0.17 \\
(0.09)\end{array}$ \\
\hline GDP growth $(t-1)$ & & & & & $\begin{array}{c}0.11 \\
(0.84)\end{array}$ & $\begin{array}{l}0.08 \\
(0.85)\end{array}$ & $\begin{array}{c}0.09 \\
(0.85)\end{array}$ & $\begin{array}{c}0.24 \\
(0.84)\end{array}$ & & $\begin{array}{c}0.15 \\
(0.84)\end{array}$ \\
\hline Equal distribution of resources $(t-1)$ & & & & & $\begin{array}{c}0.07 \\
(0.38)\end{array}$ & $\begin{array}{l}-0.002 \\
(0.39)\end{array}$ & $\begin{array}{l}0.001 \\
(0.39)\end{array}$ & $\begin{array}{l}-0.03 \\
(0.38)\end{array}$ & & $\begin{array}{l}-0.03 \\
(0.39)\end{array}$ \\
\hline Autocratization episodes share $(t-1)$ & & & & & $\begin{array}{l}4.56 \\
(3.04)\end{array}$ & $\begin{array}{c}4.51 \\
(3.05)\end{array}$ & $\begin{array}{c}4.51 \\
(3.05)\end{array}$ & $\begin{array}{l}4.39 \\
(3.04)\end{array}$ & & $\begin{array}{r}4.61 \\
(3.04)\end{array}$ \\
\hline Democratization episodes share $(t-1)$ & & & & & $\begin{array}{l}-1.21 \\
(0.99)\end{array}$ & $\begin{array}{l}-1.16 \\
(0.99)\end{array}$ & $\begin{array}{l}-1.17 \\
(0.99)\end{array}$ & $\begin{array}{l}-1.24 \\
(0.98)\end{array}$ & & $\begin{array}{l}-1.22 \\
(0.98)\end{array}$ \\
\hline Exclusive regional EDI $(t-1)$ & & & & & $\begin{array}{c}0.05 \\
(0.27)\end{array}$ & $\begin{array}{c}0.14 \\
(0.29)\end{array}$ & $\begin{array}{c}0.13 \\
(0.28)\end{array}$ & $\begin{array}{c}0.12 \\
(0.27)\end{array}$ & & $\begin{array}{c}0.19 \\
(0.29)\end{array}$ \\
\hline Presidentialism $(t-1)$ & & & & & $\begin{array}{c}0.12 \\
(0.13)\end{array}$ & $\begin{array}{l}0.10 \\
(0.13)\end{array}$ & $\begin{array}{l}0.10 \\
(0.13)\end{array}$ & $\begin{array}{l}0.09 \\
(0.13)\end{array}$ & & $\begin{array}{r}0.08 \\
(0.13)\end{array}$ \\
\hline Year & & & & & $\begin{array}{l}300.10 \\
(307.18)\end{array}$ & $\begin{array}{c}298.61 \\
(308.49)\end{array}$ & $\begin{array}{c}299.03 \\
(308.49)\end{array}$ & $\begin{array}{l}294.43 \\
(306.83)\end{array}$ & & $\begin{array}{r}287.82 \\
(306.61)\end{array}$ \\
\hline Year $^{2}$ & & & & & $\begin{array}{l}-0.15 \\
(0.15)\end{array}$ & $\begin{array}{l}-0.15 \\
(0.15)\end{array}$ & $\begin{array}{l}-0.15 \\
(0.15)\end{array}$ & $\begin{array}{l}-0.15 \\
(0.15)\end{array}$ & & $\begin{array}{l}-0.14 \\
(0.15)\end{array}$ \\
\hline Year $^{3}$ & & & & & $\begin{array}{c}0<\beta<0.0001 \\
\quad(<0.0001)\end{array}$ & $\begin{array}{c}0<\beta<0.0001 \\
\quad(<0.0001)\end{array}$ & $\begin{array}{c}0<\beta<0.0001 \\
\quad(<0.0001)\end{array}$ & $\begin{array}{c}0<\beta<0.0001 \\
\quad(<0.0001)\end{array}$ & & $\begin{array}{c}0<\beta<0.0001 \\
\quad(<0.0001)\end{array}$ \\
\hline Constant & $\begin{array}{c}0.13 \\
(0.07)\end{array}$ & $\begin{array}{c}0.03 \\
(0.08)\end{array}$ & $\begin{array}{c}0.04 \\
(0.09)\end{array}$ & $\begin{array}{c}0.11 \\
(0.06)\end{array}$ & $\begin{array}{l}-201,288.10 \\
(204,548.70)\end{array}$ & $\begin{array}{l}-200,363.00 \\
(205,420.30)\end{array}$ & $\begin{array}{l}-200,635.50 \\
(205,420.30)\end{array}$ & $\begin{array}{l}-197,478.20 \\
(204,316.20)\end{array}$ & $\begin{array}{l}-0.01 \\
(0.10)\end{array}$ & $\begin{array}{l}-193,142.70 \\
(204,170.90)\end{array}$ \\
\hline Observations & 698 & 698 & 698 & 698 & 698 & 698 & 698 & 698 & 698 & 698 \\
\hline Log Likelihood & $-1,140.23$ & $-1,141.79$ & $-1,141.80$ & $-1,140.30$ & $-1,135.93$ & $-1,138.87$ & $-1,138.86$ & $-1,135.13$ & $-1,137.99$ & $-1,133.00$ \\
\hline AIC & $2,284.46$ & $2,287.59$ & $2,287.60$ & $2,284.61$ & 2,297.87 & $2,303.73$ & $2,303.73$ & $2,296.26$ & $2,285.98$ & $2,298.00$ \\
\hline
\end{tabular}


Table C.5: OLS regressions. Left-hand-side: difference in Revised Polity score (Marshall, Gurr, and Jaggers, 2016) (e_polity2 in (Coppedge et al., 2020)) at last pre-election year $(t-1)$ and first post-election year $(t+1)$.

\begin{tabular}{|c|c|c|c|c|c|c|c|c|c|c|}
\hline & \multicolumn{10}{|c|}{ Dependent variable: } \\
\hline & \multicolumn{10}{|c|}{ Change in e_polity 2 from $t-1$ to $t+1$} \\
\hline & (1) & (2) & (3) & (4) & (5) & (6) & (7) & (8) & (9) & (10) \\
\hline Anti-pluralism & $\begin{array}{c}-0.20 \\
(0.17)\end{array}$ & & & & $\begin{array}{l}-0.48 \\
(0.25)\end{array}$ & & & & $\begin{array}{l}-0.58 \\
(0.22)\end{array}$ & $\begin{array}{l}-0.89 \\
(0.29)\end{array}$ \\
\hline Populism & & $\begin{array}{l}-0.25 \\
(0.21)\end{array}$ & & & & $\begin{array}{l}-0.34 \\
(0.23)\end{array}$ & & & $\begin{array}{l}-0.39 \\
(0.25)\end{array}$ & $\begin{array}{l}-0.49 \\
(0.26)\end{array}$ \\
\hline Cultural dimension & & & $\begin{array}{l}0.40 \\
(0.19)\end{array}$ & & & & $\begin{array}{l}0.46 \\
(0.21)\end{array}$ & & $\begin{array}{c}1.15 \\
(0.25)\end{array}$ & $\begin{array}{c}1.27 \\
(0.26)\end{array}$ \\
\hline Economic left-right & & & & $\begin{array}{l}-0.46 \\
(0.28)\end{array}$ & & & & $\begin{array}{l}-0.46 \\
(0.29)\end{array}$ & $\begin{array}{l}-1.43 \\
(0.35)\end{array}$ & $\begin{array}{l}-1.57 \\
(0.37)\end{array}$ \\
\hline Liberal Component Index $(t-1)$ & & & & & $\begin{array}{c}0.16 \\
(0.61)\end{array}$ & $\begin{array}{c}0.58 \\
(0.56)\end{array}$ & $\begin{array}{c}0.77 \\
(0.57)\end{array}$ & $\begin{array}{c}0.55 \\
(0.57)\end{array}$ & & $\begin{array}{c}0.07 \\
(0.60)\end{array}$ \\
\hline $\ln \operatorname{pcGDP}(t-1)$ & & & & & $\begin{array}{l}-0.13 \\
(0.08)\end{array}$ & $\begin{array}{l}-0.11 \\
(0.08)\end{array}$ & $\begin{array}{l}-0.10 \\
(0.08)\end{array}$ & $\begin{array}{l}-0.07 \\
(0.08)\end{array}$ & & $\begin{array}{l}-0.10 \\
(0.09)\end{array}$ \\
\hline GDP growth $(t-1)$ & & & & & $\begin{array}{c}0.19 \\
(0.84)\end{array}$ & $\begin{array}{c}0.13 \\
(0.84)\end{array}$ & $\begin{array}{c}0.02 \\
(0.84)\end{array}$ & $\begin{array}{c}0.06 \\
(0.84)\end{array}$ & & $\begin{array}{r}0.08 \\
(0.83)\end{array}$ \\
\hline Equal distribution of resources $(t-1)$ & & & & & $\begin{array}{c}0.05 \\
(0.39)\end{array}$ & $\begin{array}{l}-0.01 \\
(0.38)\end{array}$ & $\begin{array}{c}0.06 \\
(0.39)\end{array}$ & $\begin{array}{l}-0.03 \\
(0.39)\end{array}$ & & $\begin{array}{c}0.14 \\
(0.38)\end{array}$ \\
\hline Autocratization episodes share $(t-1)$ & & & & & $\begin{array}{c}4.40 \\
(3.05)\end{array}$ & $\begin{array}{c}4.44 \\
(3.05)\end{array}$ & $\begin{array}{c}4.60 \\
(3.04)\end{array}$ & $\begin{array}{c}4.55 \\
(3.05)\end{array}$ & & $\begin{array}{c}4.54 \\
(2.99)\end{array}$ \\
\hline Democratization episodes share $(t-1)$ & & & & & $\begin{array}{l}-1.21 \\
(0.99)\end{array}$ & $\begin{array}{l}-1.19 \\
(0.99)\end{array}$ & $\begin{array}{l}-1.10 \\
(0.99)\end{array}$ & $\begin{array}{l}-1.19 \\
(0.99)\end{array}$ & & $\begin{array}{l}-1.21 \\
(0.97)\end{array}$ \\
\hline Exclusive regional EDI $(t-1)$ & & & & & $\begin{array}{c}0.04 \\
(0.28)\end{array}$ & $\begin{array}{c}0.08 \\
(0.28)\end{array}$ & $\begin{array}{c}0.23 \\
(0.27)\end{array}$ & $\begin{array}{c}0.09 \\
(0.27)\end{array}$ & & $\begin{array}{l}-0.04 \\
(0.28)\end{array}$ \\
\hline Presidentialism $(t-1)$ & & & & & $\begin{array}{c}0.12 \\
(0.13)\end{array}$ & $\begin{array}{c}0.12 \\
(0.13)\end{array}$ & $\begin{array}{l}0.09 \\
(0.13)\end{array}$ & $\begin{array}{c}0.11 \\
(0.13)\end{array}$ & & $\begin{array}{r}0.15 \\
(0.13)\end{array}$ \\
\hline Year & & & & & $\begin{array}{c}303.31 \\
(307.68)\end{array}$ & $\begin{array}{c}273.82 \\
(308.42)\end{array}$ & $\begin{array}{c}260.77 \\
(307.86)\end{array}$ & $\begin{array}{c}333.85 \\
(308.70)\end{array}$ & & $\begin{array}{r}286.47 \\
(302.87)\end{array}$ \\
\hline Year $^{2}$ & & & & & $\begin{array}{l}-0.15 \\
(0.15)\end{array}$ & $\begin{array}{l}-0.14 \\
(0.15)\end{array}$ & $\begin{array}{l}-0.13 \\
(0.15)\end{array}$ & $\begin{array}{l}-0.17 \\
(0.15)\end{array}$ & & $\begin{array}{l}-0.14 \\
(0.15)\end{array}$ \\
\hline Year $^{3}$ & & & & & $\begin{array}{c}0<\beta<0.0001 \\
\quad(<0.0001)\end{array}$ & $\begin{array}{c}0<\beta<0.0001 \\
\quad(<0.0001)\end{array}$ & $\begin{array}{c}0<\beta<0.0001 \\
\quad(<0.0001)\end{array}$ & $\begin{array}{c}0<\beta<0.0001 \\
(<0.0001)\end{array}$ & & $\begin{array}{c}0<\beta<0.0001 \\
\quad(<0.0001)\end{array}$ \\
\hline Constant & $\begin{array}{c}0.09 \\
(0.07)\end{array}$ & $\begin{array}{c}0.12 \\
(0.08)\end{array}$ & $\begin{array}{l}-0.13 \\
(0.10)\end{array}$ & $\begin{array}{c}0.28 \\
(0.16)\end{array}$ & $\begin{array}{l}-203,378.20 \\
(204,879.40)\end{array}$ & $\begin{array}{l}-183,850.60 \\
(205,376.30)\end{array}$ & $\begin{array}{l}-175,190.30 \\
(204,998.30)\end{array}$ & $\begin{array}{l}-223,892.80 \\
(205,563.20)\end{array}$ & $\begin{array}{c}0.57 \\
(0.20)\end{array}$ & $\begin{array}{l}-192,387.50 \\
(201,683.30)\end{array}$ \\
\hline Observations & 698 & 698 & 698 & 698 & 698 & 698 & 698 & 698 & 698 & 698 \\
\hline Log Likelihood & $-1,141.13$ & $-1,141.07$ & $-1,139.68$ & $-1,140.43$ & $-1,137.04$ & $-1,137.73$ & $-1,136.38$ & $-1,137.59$ & $-1,128.12$ & $-1,122.29$ \\
\hline AIC & $2,286.27$ & $2,286.15$ & $2,283.35$ & $2,284.87$ & $2,300.09$ & $2,301.46$ & 2,298.76 & $2,301.17$ & $2,266.24$ & $2,276.59$ \\
\hline
\end{tabular}

